Review

\title{
Graphene as Cancer Theranostic Tool: Progress and Future Challenges
}

\author{
Marco Orecchioni' ${ }^{1}$, Roberto Cabizza ${ }^{1}$, Alberto Bianco $^{2}$ and Lucia Gemma Delogu ${ }^{1 凶}$ \\ 1. Department of Chemistry and Pharmacy, University of Sassari, via muroni 2307100 Sassari, Italy \\ 2. CNRS, Institut de Biologie Moléculaire et Cellulaire, Laboratoire d'Immunologiepathologie et Chimie Thérapeutique, 15 rue René Des- \\ cartes, 67000 Strasbourg, France
}

\section{$\square$ Corresponding author: E-mail: lgdelogu@uniss.it}

๑ 2015 Ivyspring International Publisher. Reproduction is permitted for personal, noncommercial use, provided that the article is in whole, unmodified, and properly cited. See http://ivyspring.com/terms for terms and conditions.

Received: 2014.12.18; Accepted: 2015.02.04; Published: 2015.03.28

\begin{abstract}
Nowadays cancer remains one of the main causes of death in the world. Current diagnostic techniques need to be improved to provide earlier diagnosis and treatment. Traditional therapy approaches to cancer are limited by lack of specificity and systemic toxicity. In this scenario nanomaterials could be good allies to give more specific cancer treatment effectively reducing undesired side effects and giving at the same time accurate diagnosis and successful therapy. In this context, thanks to its unique physical and chemical properties, graphene, graphene oxide (GO) and reduced graphene (rGO) have recently attracted tremendous interest in biomedicine including cancer therapy.

Herein we analyzed all studies presented in literature related to cancer fight using graphene and graphene-based conjugates. In this context, we aimed at the full picture of the state of the art providing new inputs for future strategies in the cancer theranostic by using of graphene.

We found an impressive increasing interest in the material for cancer therapy and/or diagnosis. The majority of the works (73\%) have been carried out on drug and gene delivery applications, following by photothermal therapy (32\%), imaging (31\%) and photodynamic therapy (10\%). A $27 \%$ of the studies focused on theranostic applications. Part of the works here discussed contribute to the growth of the theranostic field covering the use of imaging (i.e. ultrasonography, positron electron tomography, and fluorescent imaging) combined to one or more therapeutic modalities. We found that the use of graphene in cancer theranostics is still in an early but rapidly growing stage of investigation. Any technology based on nanomaterials can significantly enhance their possibility to became the real revolution in medicine if combines diagnosis and therapy at the same time. We performed a comprehensive summary of the latest progress of graphene cancer fight and highlighted the future challenges and the innovative possible theranostic applications.
\end{abstract}

Key words: graphene, nanomedicine, carbon materials, cancer, tumor, theranostics, therapy.

\section{Introduction}

Despite the everyday progresses of medicine solutions for human health, today cancer is still one of the biggest challenges for humanity. Thanks to the advancements in prevention and in treatment, the survival rate has been improved in the last few years. However, cancer remains one of the main causes of death worldwide with 8,2 million of death occurred in 2012. It is estimated that by 2020 , there will be between 15 and 17 million new cases of cancer every year, $60 \%$ of which will be in developing countries [1]. In economical developed countries the burden of cancer is a result of population aging and growth as 
well as an increasing adoption of cancer-associated lifestyle choices including smoking, physical inactivity, and "westernized" diets [2,3]. Cancer, as definition, is the uncontrolled growth of cells that can occur in any type of tissue and, at the late stage, these cells lose their adhesion capacities and migrate to healthy tissues. Other than surgical treatment, the different options are all based on a mechanical or pharmacological killing action against cancer cells, possibly avoiding the side effect damages of healthy cells.

Nanotechnology is one of the best promises to attack cancer cells more specifically, effectively and to reduce undesired side effects. In other terms, nanotechnology can be used to transport drugs to a specific site using specific keys such as antibodies. Moreover, in the context of developing innovative theranostics, nanomaterials could be used for imaging as a diagnostic tool and, at the same time, to stimulate and control the release of drugs in the cancer site.

In the recent years numerous nanomaterials have been explored for potential theranostic applications for cancer therapy thanks to their properties [4].

Compared to traditional molecular contrast agents or drugs, nanomaterials can be engineered to improve and integrate multiple functions in a single system also to give the control of drugs release, being of hope for the building of a next generation of anticancer tools [5].

The relatively new nanomaterial, graphene, has attracted tremendous interest in the scientific community and in the public [6-9] being explored for many potential applications due to its unique physico-chemical characteristics including electronic, optical, thermal and mechanical properties [10-12]. The precise structure of graphene has been the subject of debate over the years since it varies greatly with the preparation methods and extent of oxidation $[13,14]$. Nevertheless, graphene can be rich in functional groups such as carboxylic and hydroxyl groups which facilitate its surface modifications. Very recently, graphene and graphene oxide (GO) have been investigated in a growing number of medical applications, such as drug delivery, diagnostics, tissue engineering and gene transfection all with the final aim to use it as a theranostic materials [15-18]. However, one of the main concerns of using graphene in nanomedicine is its biocompatibility. Similarly to many other nanomaterials, it is necessary to carefully address its bio- degradability in aqueous solutions. In addition, the dimensions of the flakes of graphene could be responsible of different impacts on cell viability [19]. On the other hand, specific toxic effects of graphene on cancer cells could represent a positive point. Indeed, many reports have shown that this function of graphene could be useful in possible future therapeutic applications [20, 21], for example as an inhibitor of cancer cell metastasis [22]. Furthermore, different anticancer biomolecules such as siRNA, DNA and other drugs can be loaded onto the graphene surface for gene silencing and transfection, drug delivery and many other cancer therapy applications [23].

In this review we analyzed all studies presented in literature aiming to fight cancer using graphene and graphene-based conjugates. We found that the graphene strategies in fighting cancer can be summarized in 4 main groups: i) drug delivery, ii) photothermal therapy (PTT), iii) photodynamic therapy, (PDT) and iv) imaging. Furthermore, we evidenced the works where authors used diagnostic and different therapy strategies such as drug delivery into one system promoting the use of graphene as a theranostic tool. We also carefully evaluated the use and the impact of graphene by tumor type. Our purpose was to broaden the knowledge of graphene as useful technology for the future of clinical cancer treatment and diagnosis. In this work we point out what are the lacking areas of graphene investigation from an oncology point of view, underling what can be the most promising approaches for the use of graphene-based tools in the challenging field of cancer.

\section{Studies selection criteria and overview}

To achieve our aim, we performed a "PubMed search" using the following keywords: graphene, graphene oxide, cancer therapy, drug delivery and cancer, immunotherapy, imaging and cancer, cancer diagnosis. The keyword exploration was done in several different combinations. High impact review articles also served as additional tool. The list of reported studies includes all the retrieved publications from 2008 to November 2014. In table 1 we report a characterization of all the studies based on: type of application, type of cancer, species, model, type of graphene in terms of functionalization, year of publication and reference.

Table 1. Functionalized graphene.

\begin{tabular}{|l|l|l|l|l|l|l|}
\hline Type of applications & Type of cancer & $\begin{array}{l}\text { Tumor-cell } \\
\text { type }\end{array}$ & Model & $\begin{array}{l}\text { Drug/Imaging molecules } \\
\text { used }\end{array}$ & Graphene \\
\hline Drug Delivery and Imaging & $\begin{array}{l}\text { Burkitt's Lym- } \\
\text { phoma }\end{array}$ & Human & In Vitro & $\begin{array}{l}\text { Doxorubicin, Rituxan Fluo- } \\
\text { rescence Imaging }\end{array}$ & nGO-PEG & 2008 \\
\hline $\begin{array}{l}\text { Imaging and Photothermal X. et al (Nano Res.) } \\
\text { Therapy }\end{array}$ & Breast Cancer & Mouse & In Vivo & Fluorescence Imaging & nGS-PEG & 2010 Yang K. et al (Nanoletters) \\
\hline
\end{tabular}




\begin{tabular}{|c|c|c|c|c|c|c|c|}
\hline Drug Delivery & Breast Cancer & Human & In Vitro & $\begin{array}{l}\text { Doxorubicin and Camptothe- } \\
\text { cin }\end{array}$ & nGO-Acid Folic & 2010 & Zhang L. et al (Small) \\
\hline Drug Delivery & Breast Cancer & Human & In Vitro & Camptothecin & GO-PVA & 2011 & $\begin{array}{l}\text { Sahoo N.G. et al (Chem. } \\
\text { Comm.) }\end{array}$ \\
\hline Drug Delivery & $\begin{array}{l}\text { Breast and Colon } \\
\text { Cancer }\end{array}$ & Human & In Vitro & $\begin{array}{l}\text { Maltodextrin (MD) and EA } \\
\text { (ellagic acid) }\end{array}$ & $\begin{array}{l}\text { GO-Pluronic F38, } \\
\text { GO-Tween 80, GO-MD } \\
\text { and EA }\end{array}$ & 2011 & $\begin{array}{l}\text { Kakran M. et al (Curr. Med. } \\
\text { Chem.) }\end{array}$ \\
\hline Gene Delivery and Imaging & \begin{tabular}{|l|} 
Cervical and \\
Prostate Cancer
\end{tabular} & Human & In Vitro & $\begin{array}{l}\text { pDNA (pCMV-Luc), Fluores- } \\
\text { cence Imaging }\end{array}$ & GO-BPEI & 2011 & Kim H. et al (Bioconjug Chem.) \\
\hline $\begin{array}{l}\text { Drug Delivery and Photo- } \\
\text { thermal Therapy }\end{array}$ & Breast Cancer & $\begin{array}{l}\text { Human and } \\
\text { Mouse }\end{array}$ & \begin{tabular}{|l|} 
In Vitro and \\
In Vivo
\end{tabular} & Doxorubicin & nGO-PEG & 2011 & Zhang W. et al (Biomaterials) \\
\hline $\begin{array}{l}\text { Drug Delivery and Photo- } \\
\text { dynamic Therapy }\end{array}$ & Cervical Cancer & Human & In Vitro & Chlorin e6 & GO-PEG & 2011 & Tian B. et al (ACS Nano) \\
\hline Photodynamic Therapy & Gastric Cancer & Human & In Vitro & & GO-Folic Acid (FA) & 2011 & Huang P. et al (Theranostics) \\
\hline Photothermal Therapy & Brain Cancer & Human & In Vitro & & nano-rGO-PEG and RGD & 2011 & $\begin{array}{l}\text { Robinson J.T. et al (J. Am. } \\
\text { Chem. Soc.) }\end{array}$ \\
\hline $\begin{array}{l}\text { Imaging and Photothermal } \\
\text { Therapy }\end{array}$ & Breast Cancer & $\begin{array}{l}\text { Human and } \\
\text { Mouse }\end{array}$ & \begin{tabular}{|l|} 
In Vitro and \\
In Vivo \\
\end{tabular} & \begin{tabular}{|l|} 
Fluorescence Imaging \\
\end{tabular} & \begin{tabular}{|l|} 
rGO-QD (semiconductor \\
quantum dots)
\end{tabular} & 2012 & Hu S.H. et al (Adv. Mater.) \\
\hline $\begin{array}{l}\text { Imaging and Photothermal } \\
\text { Therapy }\end{array}$ & Breast Cancer & Mouse & \begin{tabular}{|l|} 
In Vivo \\
\end{tabular} & $\begin{array}{l}\text { Fluorescence, Photoacoustic, } \\
\text { and MR imaging }\end{array}$ & \begin{tabular}{|l|} 
rGO and rGO-iron \\
chloride hexahydrate
\end{tabular} & 2012 & Yang K. et al (Adv. Mater.) \\
\hline Drug Delivery & Brain Cancer & Human & In Vitro & $\begin{array}{l}\text { 1,3-bis(2-chloroethyl)-1-nitroso } \\
\text { urea (BCNU) }\end{array}$ & GO-PAA & 2012 & $\begin{array}{l}\text { Lu Y.J. et al (Int. J. Nanomedi- } \\
\text { cine) }\end{array}$ \\
\hline Drug Delivery & Breast Cancer & Human & In Vitro & Doxorubicin & $\begin{array}{l}\text { GN-PF127 (Pluronic } \\
\text { F127) }\end{array}$ & 2012 & $\begin{array}{l}\text { Hu H. et al (J. Biomed. Mater. } \\
\text { Res. A) }\end{array}$ \\
\hline Drug Delivery & Breast Cancer & Human & In Vitro & Adryamicin & GO & 2012 & Wu J. et al (Nanotechnology) \\
\hline Drug Delivery & Breast Cancer & Human & In Vitro & $\beta$-Lapachone & rGO-Fe $\mathrm{F}_{4}$ & 2012 & Zheng X.T. et al (Mol. Pharm.) \\
\hline Drug Delivery & Cervical Cancer & Mouse & In Vitro & Doxorubicin & NGs & 2012 & Yang Y. et al (Chemistry) \\
\hline Drug Delivery & $\begin{array}{l}\text { Cervical, Breast } \\
\text { and Lung Cancer }\end{array}$ & $\begin{array}{l}\text { Human and } \\
\text { Mouse }\end{array}$ & \begin{tabular}{|l|} 
In Vitro and \\
In Vivo
\end{tabular} & Tamoxifen Citrate & NGs & 2012 & Misra S.K. et al (Small) \\
\hline Drug Delivery & Liver Carcinoma & Human & \begin{tabular}{|l|} 
In Vitro \\
\end{tabular} & $\begin{array}{l}\text { Elsinochrome A and Doxoru- } \\
\text { bicin }\end{array}$ & rGO & 2012 & Wei G. et al (Chemistry) \\
\hline Drug Delivery and Imaging & Breast Cancer & $\begin{array}{l}\text { Human and } \\
\text { Mouse }\end{array}$ & \begin{tabular}{|l|} 
In Vitro and \\
In Vivo \\
\end{tabular} & $\begin{array}{l}\text { TRC105, Positron Emission } \\
\text { Tomography }\end{array}$ & GO & 2012 & Hong H. et al (ACS Nano) \\
\hline Imaging & Breast Cancer & Human & In Vitro & Fluorescence Imaging & $\begin{array}{l}\text { GO-Fe3O4(Fe)-PAMAM- } \\
\text { G4-NH2-Cy5 }\end{array}$ & 2012 & $\begin{array}{l}\text { Wate P.S. et al (Nanotechnol- } \\
\text { ogy) }\end{array}$ \\
\hline Photothermal Therapy & Breast Cancer & Mouse & In Vivo & & nGO-PEG & 2012 & Yang K. et al (Biomaterials) \\
\hline Photothermal Therapy & Colon Cancer & Human & In Vitro & & GT-rGO & 2012 & $\begin{array}{l}\text { Abdolahad M et al. (Mater. Sci. } \\
\text { Eng. C Mater. Biol. Appl.) }\end{array}$ \\
\hline $\begin{array}{l}\text { Imaging and Photothermal } \\
\text { Therapy }\end{array}$ & Cervical Cancer & $\begin{array}{l}\text { Human and } \\
\text { Mouse }\end{array}$ & \begin{tabular}{|l|} 
In Vitro and \\
In Vivo \\
\end{tabular} & $\begin{array}{l}\text { US imaging and X-ray CT } \\
\text { imaging }\end{array}$ & GO-Au@PLA & 2013 & Jin Y. et al (Biomaterials) \\
\hline Drug Delivery & Brain Cancer & Mouse & In Vitro & Camptothecin & GO-PDEA & 2013 & $\begin{array}{l}\text { Kavitha T. et al (Phys. Chem. } \\
\text { Chem. Phys.) }\end{array}$ \\
\hline Drug Delivery & Brain Cancer & $\begin{array}{l}\text { Human and } \\
\text { Mouse }\end{array}$ & $\begin{array}{l}\text { In Vitro and } \\
\text { In Vivo }\end{array}$ & Doxorubicin & GO-PEG-Tf (Transferrin) & 2013 & $\begin{array}{l}\text { Liu G. et al (ACS Appl. Mater. } \\
\text { Interfaces) }\end{array}$ \\
\hline Drug Delivery & Brain Cancer & Human & In Vivo & Epirubicin & NMGO-PEG & 2013 & Yang H.W. et al (Adv. Mater.) \\
\hline Drug Delivery & Breast Cancer & Human & In Vitro & $\begin{array}{l}\text { Hematin-terminated dextran } \\
\text { and Doxorubicin }\end{array}$ & $\mathrm{GO}$ & 2013 & $\begin{array}{l}\text { Jin R. et al (ACS Appl. Mater. } \\
\text { Interfaces) }\end{array}$ \\
\hline Drug Delivery & Breast Cancer & Human & In Vitro & Doxorubicin & GQDs & 2013 & Wang C. et al (Sci. Rep.) \\
\hline $\begin{array}{l}\text { Drug Delivery and Gene } \\
\text { Delivery }\end{array}$ & Breast Cancer & Human & In Vitro & $\begin{array}{l}\text { Adryamicin, siRNA (an- } \\
\text { ti-miR-21) }\end{array}$ & GO-PEI-PSS & 2013 & Zhi F. et al (Plos One) \\
\hline Drug Delivery & Cervical Cancer & Human & \begin{tabular}{|l|l} 
In Vitro \\
\end{tabular} & Doxorubicin & rGO-PEG-BPEI & 2013 & Kim H. et al (ACS Nano) \\
\hline Drug Delivery & Cervical Cancer & $\begin{array}{l}\text { Human and } \\
\text { Mouse }\end{array}$ & \begin{tabular}{|l|} 
In Vitro and \\
In Vivo \\
\end{tabular} & Doxorubicin & GO-PEG-Tf (Transferrin) & 2013 & $\begin{array}{l}\text { Liu C.W. et al (Biomacromol- } \\
\text { ecules) }\end{array}$ \\
\hline Drug Delivery & Cervical Cancer & $\begin{array}{l}\text { Human and } \\
\text { Mouse }\end{array}$ & \begin{tabular}{|l|} 
In Vitro and \\
In Vivo \\
\end{tabular} & Doxorubicin & $\begin{array}{l}\text { rGO-CHA (cholesteryl } \\
\text { hyaluronic acid) }\end{array}$ & 2013 & Miao W. et al (Biomaterials) \\
\hline Drug Delivery & Liver Carcinoma & Human & \begin{tabular}{|l|l} 
In Vitro \\
\end{tabular} & 5-fluorouracil & MGNs & 2013 & Fan X. et al (Nanoscale) \\
\hline Drug Delivery & Lung Cancer & Human & In Vitro & Paclitaxel & GO & 2013 & Arya N. et al (Nanoscale) \\
\hline Gene Delivery & Skin Cancer & Mouse & \begin{tabular}{|l|l} 
In Vivo \\
\end{tabular} & Stat3-specific siRNA & GO-PEI-PEG & 2013 & Yin D. et al (Nanotechnology) \\
\hline Drug Delivery and Imaging & Breast Cancer & $\begin{array}{l}\text { Human and } \\
\text { Mouse }\end{array}$ & \begin{tabular}{|l|} 
In Vitro, In \\
Vivo and Ex \\
Vivo \\
\end{tabular} & $\begin{array}{l}\text { TRC105, Positron Emission } \\
\text { Tomography }\end{array}$ & rGO & 2013 & Shi S. et al (Biomaterials) \\
\hline Drug Delivery and Imaging & Cervical Cancer & Human & \begin{tabular}{|l|} 
In Vitro \\
\end{tabular} & $\begin{array}{l}\text { Doxorubicin, Fluorescence } \\
\text { Imaging }\end{array}$ & GO-QDs & 2013 & $\begin{array}{l}\text { Chen M.L. et al (Bioconjug. } \\
\text { Chem.) }\end{array}$ \\
\hline Drug Delivery and Imaging & Liver Carcinoma & Human & In Vitro & Doxorubicin, MR Imaging & $\begin{array}{l}\text { GO-DTPA-Gd (diethy- } \\
\text { lenetriaminepentaacetic } \\
\text { acid-gadolinium) }\end{array}$ & 2013 & $\begin{array}{l}\text { Zhang M. et al (ACS Appl. } \\
\text { Mater. Interfaces) }\end{array}$ \\
\hline $\begin{array}{l}\text { Drug Delivery and Photo- } \\
\text { dynamic Therapy }\end{array}$ & Skin cancer & Mouse & \begin{tabular}{|l|} 
In vitro and \\
In Vivo
\end{tabular} & Doxorubicin, Chlorin e6 & $\mathrm{GO}$ & 2013 & Miao W. et al (Biomaterials) \\
\hline $\begin{array}{l}\text { Drug Delivery and Photo- } \\
\text { thermal Therapy }\end{array}$ & Brain Cancer & Human & In Vitro & Doxorubicin & $\begin{array}{l}\text { GSPI (silica-coated } \\
\text { graphene nanosheet) }\end{array}$ & 2013 & \begin{tabular}{|l|} 
Wang Y.et al \\
(J.Am.Chem.Soc.)
\end{tabular} \\
\hline $\begin{array}{l}\text { Drug Delivery and Photo- } \\
\text { thermal Therapy }\end{array}$ & Brain Cancer & Mouse & In Vitro & Epirubicin & GO-PEG-EGFR & 2013 & Yang H.W. et al (Biomaterials) \\
\hline $\begin{array}{l}\text { Photothermal, Photody- } \\
\text { namic Therapy and Imaging }\end{array}$ & Breast Cancer & $\begin{array}{l}\text { Human and } \\
\text { Mouse }\end{array}$ & \begin{tabular}{|l|} 
In Vitro, In \\
Vivo and Ex \\
Vivo \\
\end{tabular} & $\begin{array}{l}\text { Upconversion luminescence } \\
\text { imaging }\end{array}$ & GO-UCNPs--ZnPc & 2013 & Wang Y. et al (Biomaterials) \\
\hline
\end{tabular}




\begin{tabular}{|c|c|c|c|c|c|c|c|}
\hline $\begin{array}{l}\text { Drug Delivery and Photo- } \\
\text { thermal Therapy }\end{array}$ & Prostate Cancer & Mouse & In Vitro & $\begin{array}{l}\text { Doxorubicin, CGN (thermo- } \\
\text { sensitive nanogel) }\end{array}$ & rGO & 2013 & Wang C. et al (Nanomedicine) \\
\hline Imaging & Breast Cancer & Mouse & In Vivo & Computed Tomography & GO & 2013 & $\begin{array}{l}\text { Cornelissen B. et al (Bio- } \\
\text { materials) }\end{array}$ \\
\hline $\begin{array}{l}\text { Photothermal and Photody- } \\
\text { namic Therapy }\end{array}$ & Cervical Cancer & Human & \begin{tabular}{|l|} 
In Vitro and \\
In Vivo
\end{tabular} & & GO & 2013 & Sahu A. et al (Biomaterials) \\
\hline Photothermal Therapy & $\begin{array}{l}\text { Breast and Lung } \\
\text { Cancer }\end{array}$ & Human & In Vitro & & rGO-Cu ${ }_{2} \mathrm{O}$ Nanocrystal & 2013 & Hou C. et al (Nanoscale) \\
\hline Photothermal Therapy & Cervical Cancer & $\begin{array}{l}\text { Human and } \\
\text { Mouse }\end{array}$ & \begin{tabular}{|l|} 
In Vitro, In \\
Vivo and Ex \\
Vivo \\
\end{tabular} & & GO-IONPs-Au-PEG & 2013 & Shi X. et al (Biomaterials) \\
\hline Drug Delivery and Imaging & $\begin{array}{l}\text { Lung and Prostate } \\
\text { Cancer }\end{array}$ & $\begin{array}{l}\text { Human and } \\
\text { Mouse }\end{array}$ & \begin{tabular}{|l|} 
In Vitro and \\
In Vivo
\end{tabular} & $\begin{array}{l}\text { Doxorubicin and } \\
\text { GFP-plasmid, Fluorescence } \\
\text { Imaging }\end{array}$ & $\begin{array}{l}\text { CMG (Chitosan Magnet- } \\
\text { ic-Graphene) }\end{array}$ & 2013 & $\begin{array}{l}\text { Wang C et a. (J. Mater. Chem. } \\
\text { B Mater. Biol. Med.) }\end{array}$ \\
\hline Drig Delivery and Imaging & Liver Cancer & Human & In Vitro & $\begin{array}{l}\text { Doxorubicin, MR imaging and } \\
\text { Fluorescence imaging }\end{array}$ & GO-SiO2 & 2013 & $\begin{array}{l}\text { Gao Y et al (Colloids Surf. B } \\
\text { Biointerfaces) }\end{array}$ \\
\hline $\begin{array}{l}\text { Gene Delivery and Photo- } \\
\text { thermal Therapy }\end{array}$ & $\begin{array}{l}\text { Cervical and } \\
\text { Breast Cancer }\end{array}$ & Human & In Vitro & siRNA targeting Plk1 mRNA & GO-PEG-PEI & 2013 & Feng L et al (Small) \\
\hline Drug Delivery & Breast Cancer & Human & In Vitro & Anastrozole & GO-IOF/IOI/IO & 2014 & $\begin{array}{l}\text { Chaudhari N.S. et al (Mater. } \\
\text { Sci. Eng. C Mater. Biol. Appl.) }\end{array}$ \\
\hline Drug Delivery & Breast Cancer & Human & In Vitro & Camptothecin & $\begin{array}{l}\text { GO-cyclodextrin, hyalu- } \\
\text { ronated adamantane }\end{array}$ & 2014 & Zhang Y.M. (Chem. Comm.) \\
\hline Drug Delivery & $\begin{array}{l}\text { Breast and Pan- } \\
\text { creatic Cancer }\end{array}$ & Human & In Vitro & Gambocic Acid & Gs/SWCNTs & 2014 & $\begin{array}{l}\text { Saeed M.L. et al (J Appl Toxi- } \\
\text { col.) }\end{array}$ \\
\hline Drug Delivery & Cervical Cancer & Human & In Vitro & Camptothecin & GO-PVCL & 2014 & $\begin{array}{l}\text { Kavitha T. et al (Colloids Surf } \\
\text { B Biointerfaces) }\end{array}$ \\
\hline Drug Delivery & Cervical Cancer & Human & In Vitro & $\begin{array}{l}\text { Curcumin, Paclitaxol, Camp- } \\
\text { tothecin and Doxorubicin }\end{array}$ & $\begin{array}{l}\text { NGs-nile red and } \\
\text { C-folate. }\end{array}$ & 2014 & Maity A.R. et al (Nanoscale) \\
\hline Drug Delivery & Cervical Cancer & Human & In Vitro & Doxorubicin & GO-PEI & 2014 & $\begin{array}{l}\text { Chen H. et al (ACS Appl. } \\
\text { Mater. Interface) }\end{array}$ \\
\hline Gene Delivery & Colon Cancer & $\begin{array}{l}\text { Human and } \\
\text { Mouse }\end{array}$ & \begin{tabular}{|l|} 
In Vitro and \\
In Vivo
\end{tabular} & dsDNA & GO & 2014 & $\begin{array}{l}\text { Joseph D. et al (ACS Appl. } \\
\text { Mater. Interfaces) }\end{array}$ \\
\hline Drug Delivery & $\begin{array}{l}\text { Glioblastoma and } \\
\text { Breast Cancer }\end{array}$ & $\begin{array}{l}\text { Human and } \\
\text { Mouse }\end{array}$ & In Vitro & Lucanthone & GO-PEG-DSPE & 2014 & $\begin{array}{l}\text { Chaudhary S.M. et al (Nano- } \\
\text { medicine) }\end{array}$ \\
\hline Drug Delivery & Liver Carcinoma & Human & In Vitro & Camptothecin & GO & 2014 & Yang X. et al (Nanoscale) \\
\hline Drug Delivery & Liver Carcinoma & $\begin{array}{l}\text { Human and } \\
\text { Mouse }\end{array}$ & \begin{tabular}{|l|} 
In Vitro and \\
in Vivo \\
\end{tabular} & Doxorubicin & $\begin{array}{l}\text { GO-HA (hyaluronic } \\
\text { acid) }\end{array}$ & 2014 & $\begin{array}{l}\text { Song E. et al (ACS Appl. } \\
\text { Mater. Interfaces) }\end{array}$ \\
\hline Drug Delivery & Liver Carcinoma & Human & In Vitro & Doxorubicin & GO-PEG-alginate & 2014 & Zhao X. et al (Langmuir) \\
\hline Drug Delivery & Lung Cancer & Human & In Vitro & Paclitaxel & GO-PEG & 2014 & $\begin{array}{l}\text { Xu Z. et al (ACS Appl. Mater. } \\
\text { Interfaces) }\end{array}$ \\
\hline Drug Delivery and Imaging & Cervical Cancer & Human & In Vitro & $\begin{array}{l}\text { Doxorubicin, Fluorescence } \\
\text { Imaging }\end{array}$ & $\begin{array}{l}\text { GO Capped Mesoporous } \\
\text { Silica }\end{array}$ & 2014 & He D. et al (Langmuir) \\
\hline Drug Delivery and Imaging & Colon Cancer & Human & \begin{tabular}{|l|} 
In Vitro and \\
in Vivo \\
\end{tabular} & Curcumin & NGs Quantum Dot & 2014 & Some S. et al (Sci. Rep.) \\
\hline Drug Delivery and Imaging & Liver Carcinoma & Human & In Vitro & Curcumin, Optical Imaging & GO-RGD-Chitosan & 2014 & $\begin{array}{l}\text { Wang C. et al (Colloids and } \\
\text { Surf. B Biointerfaces) }\end{array}$ \\
\hline $\begin{array}{l}\text { Drug Delivery and Photo- } \\
\text { dynamic Therapy }\end{array}$ & Lung Cancer & Human & In Vitro & $\begin{array}{l}\text { Hypocrellin A and Camptoth- } \\
\text { ecin }\end{array}$ & rGO & 2014 & $\begin{array}{l}\text { Zhou L. et al (J. Photochem. } \\
\text { Photobiol. B) }\end{array}$ \\
\hline $\begin{array}{l}\text { Drug Delivery and Photo- } \\
\text { thermal Therapy }\end{array}$ & Breast Cancer & $\begin{array}{l}\text { Human and } \\
\text { Mouse }\end{array}$ & \begin{tabular}{|l|} 
In Vitro and \\
In Vivo \\
\end{tabular} & Doxorubicin & GO-Au & 2014 & Shi J. et al (Biomaterials) \\
\hline $\begin{array}{l}\text { Drug Delivery and Photo- } \\
\text { thermal Therapy }\end{array}$ & Cervical Cancer & $\begin{array}{l}\text { Human and } \\
\text { Mouse }\end{array}$ & \begin{tabular}{|l|} 
In Vitro and \\
In Vivo \\
\end{tabular} & Doxorubicin & PEG-GO/Cus & 2014 & Bai J. et al (Biomaterials) \\
\hline $\begin{array}{l}\text { Drug Delivery and Photo- } \\
\text { thermal Therapy }\end{array}$ & Cervical Cancer & Human & In Vitro & Doxorubicin & $\begin{array}{l}\text { rGO Capped Mesopo- } \\
\text { rous Silica }\end{array}$ & 2014 & Wan H. et al (Nanoscale) \\
\hline $\begin{array}{l}\text { Drug Delivery, Imaging and } \\
\text { Phototermal Therapy }\end{array}$ & Breast Cancer & Human & In Vitro & Doxorubicin & NGsAu nanocrystal & 2014 & Bian X. et al (Sci. Rep.) \\
\hline Imaging & Breast Cancer & Human & In Vitro & Colorimetric Assay & $\begin{array}{l}\text { GO-PtNPs (porous } \\
\text { platinum nanoparticles) }\end{array}$ & 2014 & Zhang L.N. et al (Anal. Chem.) \\
\hline $\begin{array}{l}\text { Photodinamic Theraphy and } \\
\text { Imaging }\end{array}$ & Cervical Cancer & Human & In Vitro & Fluorescence Imaging & NGs-QDs & 2014 & Ge J. et al (Nat Commun.) \\
\hline $\begin{array}{l}\text { Photothermal Theraphy and } \\
\text { Imaging }\end{array}$ & Pancreatic cancer & Human & \begin{tabular}{|l|} 
In Vitro and \\
In Vivo \\
\end{tabular} & MR imaging & GO-ION & 2014 & Wang S. et al (Biomaterials) \\
\hline Photodynamic Therapy & Breast Cancer & Mouse & In Vitro & & GO-PEG & 2014 & Rong P. et al (Theranostics) \\
\hline $\begin{array}{l}\text { Photothermal, Photody- } \\
\text { namic Therapy and Imaging }\end{array}$ & Cervical Cancer & Human & In Vitro & Fluorescence and MR imaging & $\begin{array}{l}\text { MFG (magnetic and } \\
\text { fluorescent graphene) }\end{array}$ & 2014 & $\begin{array}{l}\text { Gollavelli G. et al (Biomateri- } \\
\text { als) }\end{array}$ \\
\hline $\begin{array}{l}\text { Photothermal Theraphy and } \\
\text { Imaging }\end{array}$ & Breast Cancer & Human & In Vitro & Reman Imaging & GO and GOAuNS & 2014 & $\begin{array}{l}\text { Nergiz S.Z. et al (ACS Appl. } \\
\text { Mater. Interfaces) }\end{array}$ \\
\hline Photothermal Therapy & $\begin{array}{l}\text { Epidermoid Car- } \\
\text { cinoma }\end{array}$ & $\begin{array}{l}\text { Human and } \\
\text { Mouse }\end{array}$ & \begin{tabular}{|l|} 
In Vitro and \\
In Vivo
\end{tabular} & & GO-PEG-AuNR & 2014 & $\begin{array}{l}\text { Dembereldorj U. et al (Photo- } \\
\text { chem Photobiol) }\end{array}$ \\
\hline Drug Delivery and Imaging & Glioma & Human & In Vitro & Doxorubicin, MR imaging & $\begin{array}{l}\text { MGSPI(Magnetic gra- } \\
\text { phene mesoporous silica) }\end{array}$ & 2014 & Wang Y. et al (Small) \\
\hline Drug Delivery & Colon Cancer & Mouse & \begin{tabular}{|l|} 
In Vitro and \\
In Vivo \\
\end{tabular} & $\begin{array}{l}\text { Doxorubicin, Camptothecin, } \\
\text { Oxaliplatin and Cisplatin }\end{array}$ & GO & 2014 & Chen GY et al (Biomaterials) \\
\hline $\begin{array}{l}\text { Drug Delivery and Photo- } \\
\text { thermal Therapy }\end{array}$ & Breast Cancer & Human & In Vitro & Doxorubicin & \begin{tabular}{|l|} 
GO-PEG-DA \\
(2,3-dimethylmaleic \\
anhydride)
\end{tabular} & 2014 & $\begin{array}{l}\text { Feng L et al (Adv. Healthc. } \\
\text { Mater.) }\end{array}$ \\
\hline Photothermal Therapy & Gastric Cancer & Human & In Vitro & & rGO, GO & 2014 & $\begin{array}{l}\text { Li J.L. et al (J Biomed Mater } \\
\text { Res A.) }\end{array}$ \\
\hline
\end{tabular}


The trend (Figure 1), from 2008 to 2014, shows an impressive increasing interest in graphene for cancer therapy; i.e. the number of publications in 2013 and 2014 triplicated from 2012. Focusing on the type of application, we found that the majority of the works (73\%) have been carried out on drug delivery and gene delivery (Figure 2A). The potential to act as a delivery tool against tumor cells seems to be one of the most attractive areas for scientists. In particular, compared to carbon nanotubes [24-26], graphene has two exposed side surface and, thus, at least a double external surface area than nanotubes that improve the conjugation capacity [27]. The particular arrangement of carbon atoms favors the non covalent complexation of drugs onto its surface, making possible a better release of drugs to the targeted cells. This characteristic can be one of the reasons why graphene has raised great success in drug delivery applications for cancer therapy. Intriguingly, part of the studies used GO for drug delivery combined with other purposes, such as imaging, acquiring the ability to perform and follow the drug release.

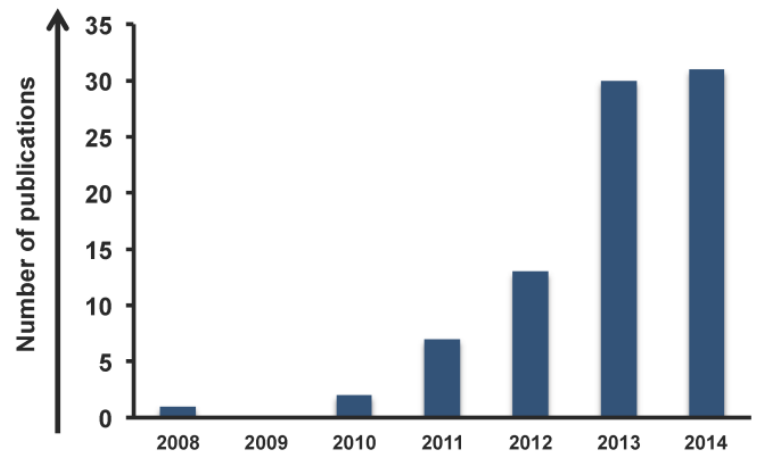

Figure 1. Percentage of publications of graphene in cancer fight (2008 to November 2014).

Photothermal therapy is the second biggest portion of works here analyzed with a portion of $32 \%$ (Figure 2A). In this context the material become attractive since it has a large surface area, is lightweight, exhibits high strength and electrical conductivity and is capable of generating plasmon, fluorescence, and nonlinear emission [5]. In particular, phototermal therapy uses the capacity of graphene to absorb light in the near-infrared region (NIR). Irradiation at 808 $\mathrm{nm}$ has been exploited, for example, in the ablation of many types of tumors both in vitro and in vivo in animal model [28].

Imaging application is in the third position in terms number of works related to cancer with $31 \%$ of the contributions (Figure 2A). Nanotehcnology imaging is very fruitful field and in the last few years has attracted many researchers aiming at testing the characteristics of numerous nanomaterials, such as carbon nanotubes [29] and quantum dots, as contrast agents [30] (Qdots) and graphene. Finally, a small part of the applications is occupied by photodynamic therapy (10\%). The Venn diagram (Figure 2B), also shows 18 studies that used graphene for combining imaging and other cancer therapy, which further confirms and emphasizes the interest on this nanomaterial for cancer diagnosis and therapy at the same time. The works on graphene as theranostic tool cover the $27 \%$.

Indeed, part of the works herein cited cover the use of imaging (ultrasonography, positron electron tomography (PET), fluorescent imaging) combined to one or more therapeutic action at the same time as showed in the Venn diagram (Figure 2B).

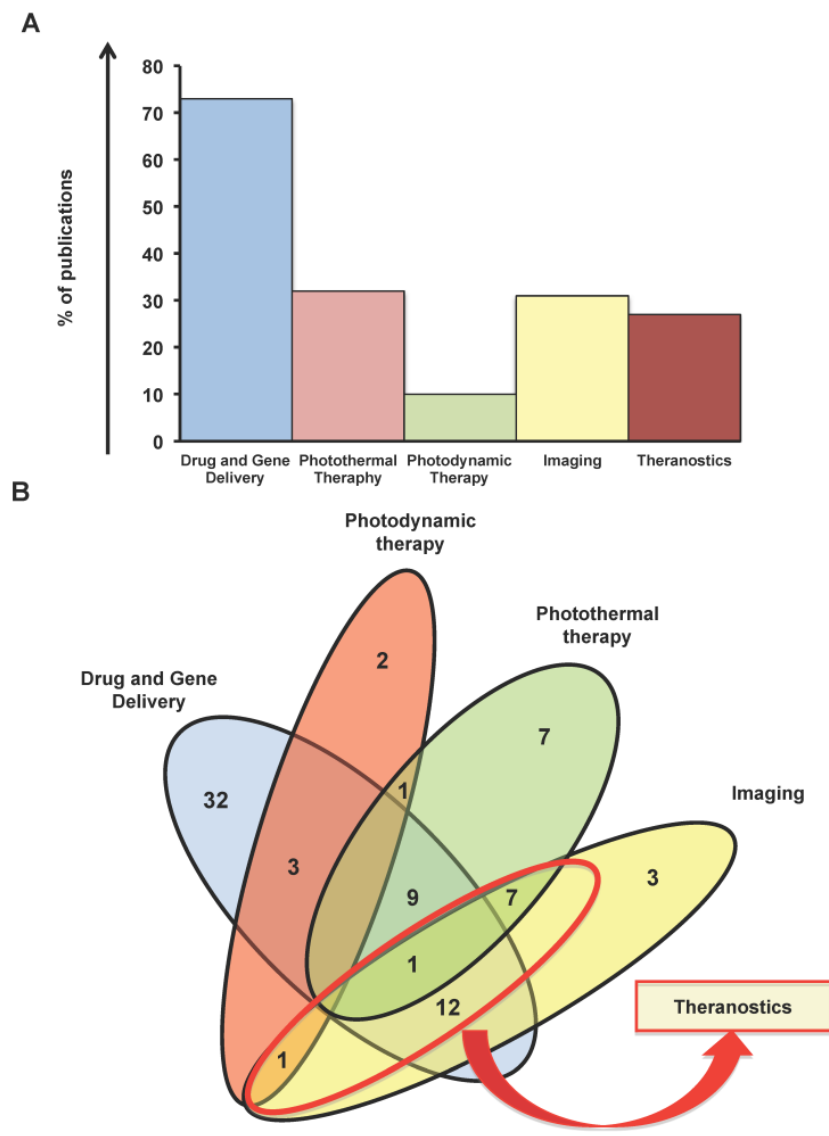

Figure 2. Status of Graphene publications in the last 7 years for cancer fight. A) Percentage of manuscripts based on the applications against cancer. B) Venn diagram based on the main applications (Drug Delivery, Phototermal therapy, Photodynamic therapy, Imaging). In the red round the theranostic studies.

We then decided to focus on the different types of cancer taken into consideration (Figure 3). Breast cancer is the most studied with a $35 \%$ of publications. Breast cancer is the most frequently diagnosed cancer in the world and the leading cause of cancer death in women, accounting for $25 \%$ (1.63 millions) of the total new cancer cases and 6,4\% (0.522 millions) of the total 
cancer deaths in 2012 [31]. About half of the breast cancer cases and $60 \%$ of the deaths are estimated to occur in Asian countries such as Iran, India and Qatar [2]. The second biggest portion is occupied by cervical cancer with a $23 \%$ of the total cases. Liver cancer is studied by $9 \%$ of the studies and the other cancers such as lymphoma, glioblastoma, glioma lung cancer, colon cancer, prostate cancer, brain cancer, pancreatic cancer and skin cancer takes the remaining part of the pie, with a range from $1 \%$ to $8 \%$ (Figure 3 ).

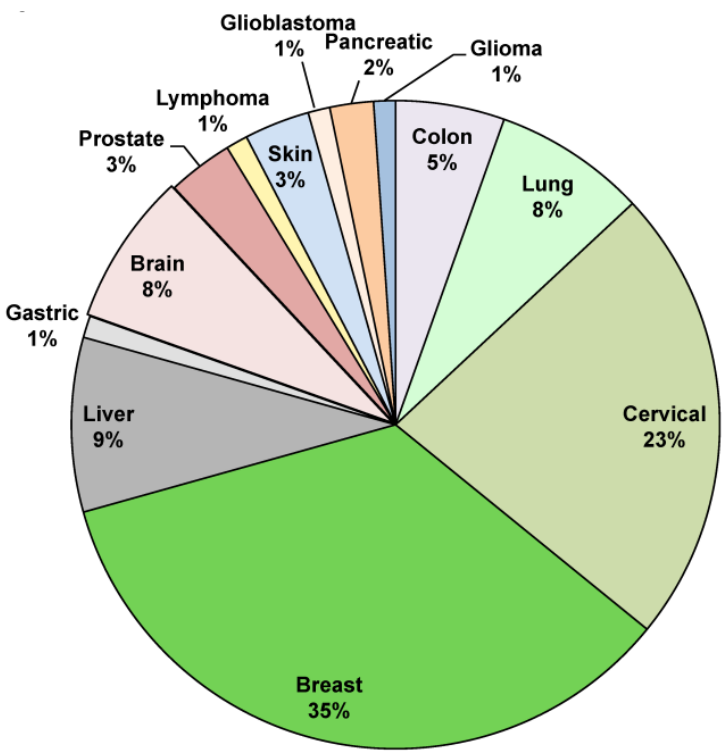

Figure 3. Overview on different type of cancer treated with graphene. Manuscripts percentages per type of studied cancer.

\section{Drug and Gene Delivery}

In recent years graphene and the other members of the family including GO and reduced GO (rGO) have been investigated for biological and biomedical applications thanks to their possible biocompatibility [32]. Moreover, the extremely large surface area of the material, with every atom exposed on its surface allow ultra-high drug and gene loading efficiency [27]. All these properties make graphene an optimal candidate as drug carrier and gene delivery system as reported in table $\mathbf{1}$ [15, 32-92].

The good drug loading ability of graphene encouraged many researchers to explore it in many different types of cancer. According to the general trend, the most studied tumor, with $31 \%$ of the total works, is breast cancer (Figure 5A) [15, 32, 34, 36, 39-41, 43, $45,49-51,58,65,66,72,81,86,89,92]$, followed by cervical cancer $[35,37,42,43,52-54,59,63,67,68,77$, $78,82,89]$ and liver cancer $[44,55,72-75,79,85,88]$ with $23 \%$ and $10 \%$ respectively.

Other cancer types such as Burkitt's lymphoma [33], colon cancer $[34,70,71,78,91]$, prostate cancer
$[35,64,87]$, lung cancer $[43,56,63,76,80,87]$, skin cancer [57, 60], brain cancer [20, 38, 46-48, 61, 62], glioma [90] and glioblastoma [72] were studied under different drug treatment conjugated with graphene or graphene oxide.

\section{Drug Delivery}

As previously mentioned, drug delivery is the first application of graphene in terms of number of studies. We found 61 works that used graphene for drug and gene delivery alone or combined with other types of modalities to treat cancer (Figure 2B), such as PTT (10 works), PDT (3 works), and in imaging (13 works). A big challenge in this perspective is to perform a good drug functionalization. Indeed, different approaches have been applied to load drug molecules onto graphene by different binding strategies. Many studies used polyethylene glycol (PEG) to increase the biocompatibility and physiological stability of graphene or graphene oxide and subsequently load anticancer drugs via non covalent interaction [32]. Liu et al. [47] functionalized the surface of GO-PEG with different ligands such as transferrin and doxorubicin (DOX) to target brain tumors. The conjugated nanosystems with trasferrin and doxorubicin displayed a greater intracellular delivery efficiency and stronger cytotoxicity against glioma.

Regarding GO, it is certainly more investigated compared to pristine graphene for drug delivery purposes. Zhang et al. [15] proposed a very innovative approach to exploit functionalized GO in biomedical research. The authors used first sulfonic acid groups functionalization (to make GO stable in physiological solutions) followed by covalent binding of folic acid targeting specifically MCF-7 cells, a human breast cancer cell line expressing folic acid receptors. They demonstrated that this system loaded with two anticancer drugs (DOX and camptothecin) showed specific targeting MCF-7 cells and a remarkably high cytotoxicity compared to the material only loaded with one of the two drugs.

DOX is a widely used chemotherapy agent and it can be loaded onto graphene via simple $\Pi-\Pi$ stacking with high efficiency, resulting very promising to target the cancer. Thanks to this behavior, 31 studies were performed aiming at the delivery of DOX by graphene (Figure 4) $[33,36,39,42,47,49,50,53,54,61$, $63,64,68,69,74,75,77,81-85,87,88,90-92]$. One of these studies used GO as a potential alternative to cross blood brain barrier in order to destroy cancer cells by the action of DOX [47]. Another approach used by Zhang et al. [36] evidenced the possibility of GO-PEG-DOX conjugate to combine the local specific chemotherapy with external near-infrared (NIR) photothermal therapy, which significantly improved 
the therapeutic efficacy of the cancer treatment. Moreover, GO was used to load two or more drugs onto its surface at the same time $[15,33,44,68]$.

We found camptotecin (CPT) as the second most conjugated drug to graphene (Figure 4). Sahoo et al., for example, described GO-poly(vinyl alcohol) (PVA) as drug carrier for $\mathrm{CPT}$ via non covalent interactions [32]. GO-PVA-CPT exhibited higher cytotoxic activity versus cancer cells compared to CPT alone. A lot of drugs were used in multiple conjugations with graphene such as camptothecin [32, 66], 1,3-bis(2-chloroethyl)-1-nitrosourea (BCNU) [38], a commercial chemotherapeutic drug for treating malignant brain tumors, tamoxifen citrate [43], elsinochrome A [44], adriamycin [40], $\beta$-lapachone [41], lucanthone [72], paclitaxel [56, 76], anastrozole [65], 5-fluorouracil [55], epirubicin [48, 62], curcumin [68], gambogic acid [86] ellagic acid [34], oxaliplatin (OXA) [91], cisplatin [91] and thermosensitive nanogel [64]. All these studies showed a great improvement in therapeutic efficacy when the drugs were loaded onto graphene. These promising data underline also the abilities of graphene as chemosensitizer. In this regard, Chen et al. tested GO with different drugs (DOX, CPT, OXA and cisplatin (CDDP)) for the treatment of colon cancer cells (CT26 cells). They have shown that GO tested together with CDDP dramatically decreased the cell viability compared to the CDDP alone on resistant cells. The authors attributed this behavior to the capacity of GO to induce moderate levels of autophagic flux and also to potentiate nuclear import of the autophagy marker LC3 and CDDP $[70,91]$.

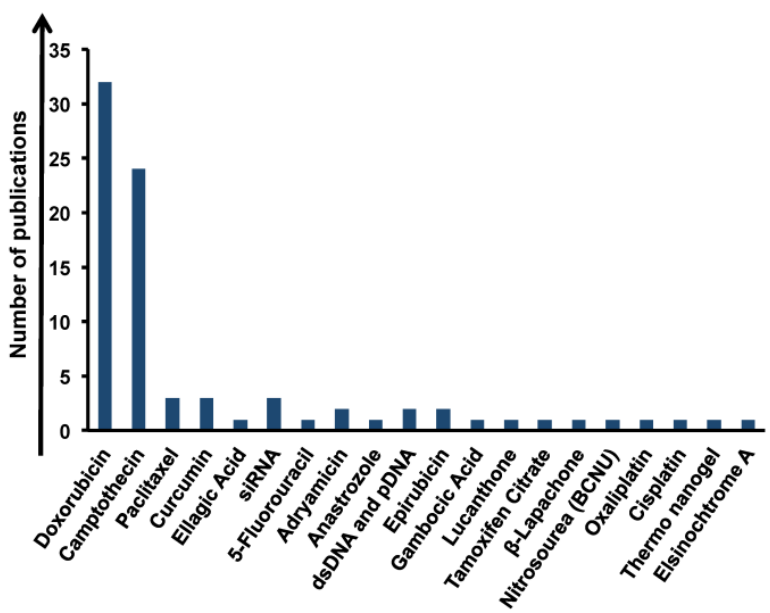

Figure 4. Analysis of the amount of publications of graphene in drug delivery applications based on type of loaded drugs.

\section{Gene delivery}

Graphene-based materials have been also widely used for gene therapy as smart gene (siRNA, dsDNA and antisense oligonucleotides) carriers, for their po- tential in the treatment of gene related diseases including cancer $[35,51,57,71,89]$. Zhi et al., for example, successfully used GO for co-delivery of drug (adriamicin) and siRNA against miRNA-21 (anti-miR-21) that is responsible of multidrug resistance in breast cancer cells. They found that the treatment with GO as a carrier of chemotherapeutic drugs and siRNA is favorable for the treatment of drug resistant cancers restoring the chemosensitivity of anticancer drugs [51]. Another remarkable study performed by Yin et al. focused on melanoma [57], an aggressive disease characterized by a complex etiology where immunotherapy and targeted therapy seems to be promising ways to fight it $[93,94]$. In this context, the authors evidenced the use of GO as a carrier of plasmid-based Stat3 siRNA. Their results indicated significant regression in tumor growth and tumor weight after treatment without any collateral toxicity in vivo mouse model [57].

\section{Photothermal Therapy}

We found that the second most studied application is the photothermal therapy (PTT) (Figure 2A). Recent publications have shown the interesting potential of GO for PTT applications (see Table 1) [28, $36,61-64,81-84,95-109]$. PTT has been reported either alone $[95,98,99,105,108-110]$ or in combination with drugs $[36,61,62,64,82,104,111]$ or with PDT [102, 103, 106] or in both (Figure 2B). Photosensitizing agents are employed in PTT to generate heat from light absorption, leading to photoablation of cancer cells and subsequent cell death. To avoid nonspecific heating of healthy cells, photosensitizers must show absorption in the near-infrared region [112] and selective uptake in cancerous cells over normal cells. Deep penetration and negligible nonspecific photothermal heating in the NIR window are due to the transparency and low absorption of light by tissues in this optical window. Nowadays, a lot of nanomaterials are under investigation for their high optical absorbance in NIR for PTT including gold nanoshells [113], gold nanorods [114], gold pyramids [115], single-walled carbon nanotubes (SWCNTs), and multi-walled carbon nanotubes (MWCNTs) [116]. Robinson et al. [95] used rGO non covalently PEGylated and conjugated to a peptide for targeting and selective photoablation of cancer cells at a low doses. Abdolahad et al. [99] used rGO linked to the aromatic rings of green tea. Green tea is well known for its possible anticancer activity; indeed its polyphenol groups could be bound to cancer cell surface receptors. One of the important agents for this binding process is epigallocatechin gallate, the main polyphenol in green tea, which binds to the cancer cell surfaces. Thanks to the properties of green tea, the authors used low 
concentration of reduced GO-green tea and had applied laser power in the PTT of colon cancer cells to obtain also high ablation efficiency [99]. It is also interesting to note that 7 studies $[28,84,97,100,101,107$, 117] (Figure 2B) evidenced the use of graphene at the same time for imaging and PTT. Bian et al. [84] used graphene $\mathrm{Au}$ nancrystals for combining PTT with imaging and DOX delivery against breast cancer cells. They performed a controlled release of DOX molecules from graphene nanocrystals through NIR heating, this system significantly reduced the possibility of side effects compared to general chemotherapy.

As for drug delivery applications, the most studied tumor for PTT graphene-based treatment is breast cancer with the $42 \%$ of the works $[28,36,81,96$, $98,100,102,104]$, followed by cervical cancer $(26 \%)$ (Figure 5B) [37, 63, 82, 101, 103, 105, 106]. The other cancers treated with graphene in PTT modality comprise brain cancer $(10 \%)$ [61, 62, 95] and lung cancer $(7 \%)[63,104]$. The remaining $15 \%$ of studies [64, 99, $108,109]$ focus on prostate, pancreatic skin, colon and gastric cancer (Figure 5B).

We found a growing interest in graphene breast cancer applications. Zhue et al. [118] i.e. discovered that GO was able to selectively down-regulate PGC-1a in breast cancer cells with a consequent inhibition of ATP production. Furthermore, GO was able to impair the assembly of the F-actin cytoskeleton, which are required for the migratory and invasive phenotype of breast cancer. Taken together these effects of GO on cancer cell metastasis may allow the development of a new approach to treat metastatic breast cancer. The strong optical absorbance of the material in the NIR window prompted many scientists to test this property in PTT against breast cancer $[28,36,81,96,98,100,102,104]$.

Yang et al. [28] reported the first experiments on this area using a GO-PEG for in vivo PTT and imaging. The imaging modality revealed high uptake of graphene in several xenograft tumor mouse breast cancer models; a robust optical absorbance, an ultra-efficient tumor ablation after intravenous administration under low-power NIR laser irradiation was achieved. No significant side effects were detected reporting the first success in using carbon nanomaterials for efficient in vivo PTT by intravenous administration.

\section{A Drug Delivery and Gene Delivery}

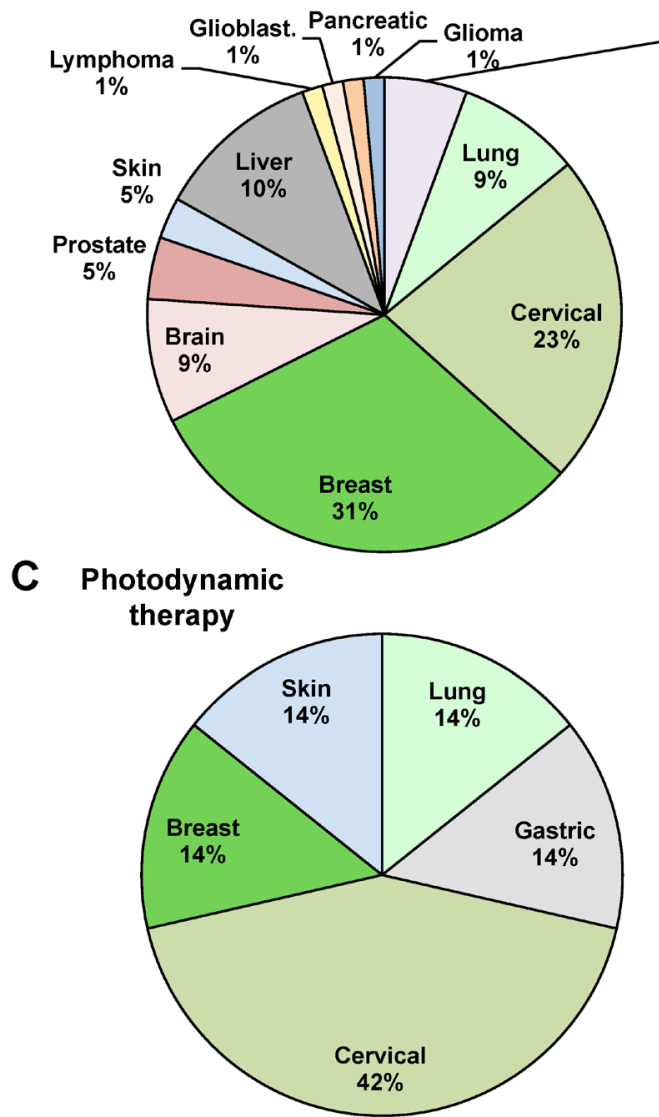

B

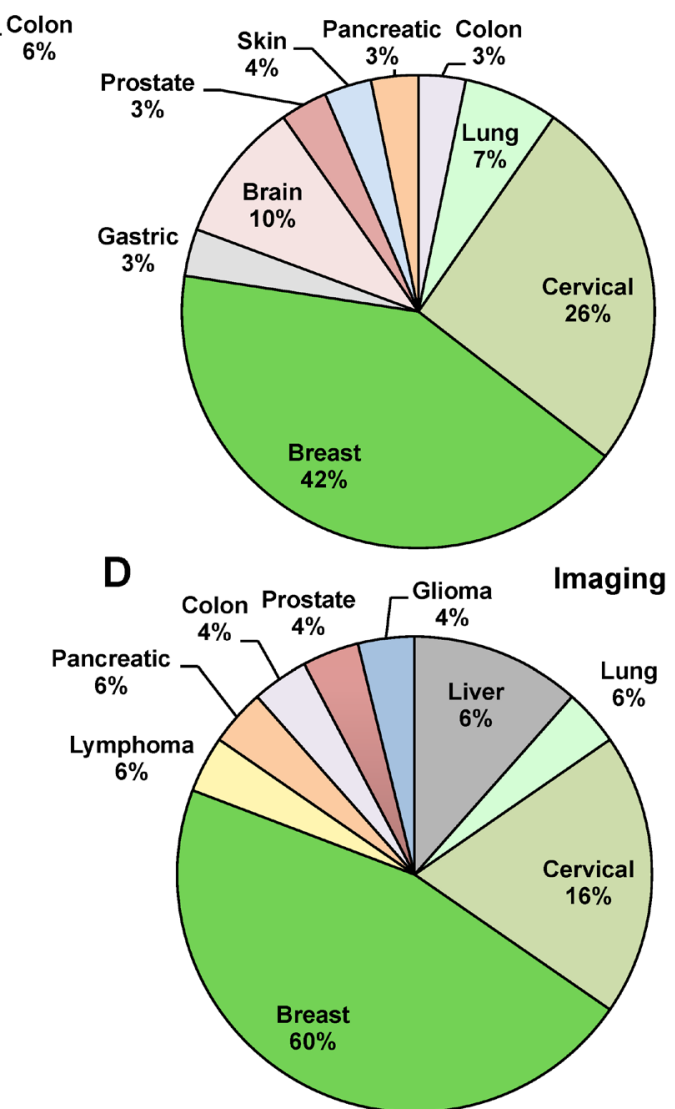

Figure 5. Paper analysis in terms of percentage of manuscripts divided by type of applications and type of cancer. 
In the context of cervical cancer, Bai et al. [82] demonstrated that the combination of PTT and drug delivery, can be a potential treatment in the battles against cancer. The authors developed a synergistic therapy based on CUS nanoparticles decorated with a PEGylated GO. GO-PEG/CuS had high storage capacity for DOX and a high photothermal conversion efficiency achieving the ablation of cervical tumor in vitro and in vivo.

Moreover, Zhang et al. [36] described the use of GO-PEG-DOX conjugate to improve the ablation of tumor both in vitro and in vivo. Indeed, the ability of the GO-PEG-DOX complex to combine the local specific chemotherapy with external NIR PTT significantly improved the therapeutic efficacy of the cancer treatment. Compared with chemotherapy or PTT alone, the combined treatment demonstrated that the synergistic effect result in a higher therapeutic efficacy. Furthermore, as shown in the Venn diagram different works successfully used graphene for the combination of PTT and imaging modalities (Figure 2B) $[28,84,97,100,101,107]$.

\section{Photodynamic Therapy}

Graphene in the very last few years has been also tested as agent in photodynamic therapy thanks to its physical properties [60, 80, 103, 106, 119]. However, despite PDT is an FDA approved modality for the local treatment of a wide variety of tumor diseases, such as esophageal cancer and lung cancer [120], the number of works that used graphene in PDT are still very few, only $10 \%$ of the total (Figure $2 \mathrm{~A}$ ) [37, 60, 80, $103,106,110,119,121]$.

Otherwise, graphene was used in concert with PDT and imaging in 2 studies (Figure 2B) carried out by Sahu et al. [103] and Gollavelli et al. [106] giving new input for future studies on the use of the material for targeting and killing cancer cells also with PDT.

Interestingly, differently from the other applications, $42 \%$ of the works in PDT focused on cervical cancer (Figure 5c). The other types of cancer explored were breast cancer and gastric cancer. PDT is based on photosensitizers sensitive to light upon suitable irradiation that produces reactive oxygen species (ROS), such as singlet oxygen, free radicals, or peroxides, inducing cytotoxicity. Compared with chemotherapy or radiotherapy, PDT shows relatively minimal side effects and improves tumor specific killing [122].

Despite the few studies in this field, all cited works described the efficient capacity of the carbon material to be loaded with different types of photosensitizers with a high action on cancer cell thanks to the PDT approach [80, 103, 123]. Zhou et al. [80] for example have combined GO with hypocrellin A proposing it as a new second-generation photosensitizer.
However, the loading of GO with hypocrellin A improved the hydrosolubility but reduced the anticancer activity. To solve this problem, GO was co-loaded with a second anticancer agent to perform at the same time two anticancer treatments. Their results showed that the combination of two therapies exhibited a synergistic antiproliferative effect compared with PDT and chemotherapy alone. The majority of the analyzed works combined PDT with other types of anticancer strategies $[103,106]$. In the work of Sahu et al. [103] GO was non-covalently functionalized with pluronic block copolymer and complexed with methylene blue, a hydrophilic and positively charged photosensitizer to combine PDT and PTT versus cancer. The release of the photosensitizer from GO surface was $\mathrm{pH}$-dependent and an acidic condition increased the release rate considerably. This nanocomplex showed enhanced uptake by cancer cells than normal cells and, when cells were irradiated with selective NIR laser lights, it induced significant cell death. This work showed the potential of GO for a synergistic combination of PDT with PTT. On the other hand, Huang et al. [119] described the GO absorption of the photosensitizer named Chlorin e6 (Ce6). GO-Ce6 accumulation in tumor cells led to a remarkable photodynamic efficacy on cancer gastric cells upon irradiation. Overall, the works we described showed the great potential of graphene in PDT alone or in concert with other cancer treatments.

\section{Imaging}

In the context of imaging, graphene have been explored to improve the diagnosis and also the treatment of cancer with the aim to avoid several side effect related with the current use of toxic chemicals as contrast agents. Most fluorescent molecular dyes (i.e. Qdots), because of their intrinsic toxicity, are not suitable for the diagnosis in many cancer patients that may already have chemotherapy-related damages to liver or kidney [124]. The excellent photostability of graphene-based nanomaterials makes them suitable for many biological imaging techniques such as photoacoustic imaging (PI), ultrasonography (US), magnetic resonance imaging (MRI), computed tomography (CT) and optical imaging applications (see table 1) $[28,33,35,45,58,59,77,78,85,87,88,96,97$, $100-102,111,125,126]$. The optical imaging potential of graphene was well studied by many reports [88, 125]. Gao et al. reported a GO-based fluorescent magnetic hybrid for loading and delivery of Doxorubicin. They applied GO for in vitro tumor cellular imaging and showed high uptake of GO into hepatocellular carcinoma cell line with a strong fluorescence. These data have evidenced the GO abilities as an optical imaging tool [88]. Regarding ultrasonography, 
our group showed in a previous study that GO has good echogenic properties with a promising future in the scenario of ultrasound contrast agents [29]. Moreover graphene could be useful also in MRI. The magnetic graphene complexes that could be useful for MRI and, at the same time, for other imaging or therapy modalities are of particular interest $[87,90,97$, $106,117,127]$. Wang et al. used magnetic a graphene complex for metastatic pancreatic cell diagnosis in the lymphonodes. At the same time they were able to directly guide the PTT therapy against cancer cells [117]. Gollavelli et al. used the ability of magnetic graphene as a potential theranostic nanocarrier for MRI and fluorescence dual modality imaging and for PDT and PTT [106]. Furthermore, it is interesting to evidence the potential of graphene as an in vitro detection tool (IVD); Zhang et al. developed a new colorimetric assay for the direct detection of cancer cells using graphene as a signal transducer [128]. Moreover in the IVD field, graphene was also used as a biosensor for molecular marker analysis in cancer diagnosis [129].

We found $31 \%$ of the total studies used graphene for cancer imaging and this percentage is expected to grow fast in few years (Figure 2A). Furthermore, graphene was almost always used in imaging with the therapy approaches cited before (Figure 2B). Thus, many authors, thanks to the good imaging characteristics of graphene, combined with encouraging results diagnosis with therapy (i.e. drug delivery or phototermal therapy) [58, 59, 96, 106, 111, 117, 126]. Moreover, the majority of the works addressed breast cancer as target model cancer with a $60 \%$ of the total studies (Figure 5D). In accordance with the other applications, the second most investigated tumor for imaging was cervical cancer (Figure 5D). Shi et al., [58] for example, studied the specific targeting of functionalized rGO conjugates to murine breast cancer in vivo. The authors used rGO loaded with a specific antibody to endoglin (CD105) for active tumor targeting in living subjects using positron emission tomography (PET) imaging. Hu et al. [96] used graphene presenting multiple functions into a single system: imaging, drug delivery and photothermal therapy. In this study NIR potential of GO was combined with the good fluorescence of Qdots. To avoid the fluorescence quenching induced by GO, a spacer was inserted between GO and the dye. This nanosystem was able to kill breast cancer cells and also served as optical indicator to monitor the therapeutic progress by fluorescence imaging. Otherwise, the combinations of GO and Qdots need more studies for its biomedical use in therapy to better understand the possible toxicity of this nanoconjugate. Nevertheless, the use of graphene and Qdots is frequently investi- gated to improve the imaging ability of graphene. Among the works that combined imaging and PTT, Yang et al. [28] published one of the first studies that used this strategy. They found in vivo fluorescence imaging revealed surprisingly high tumor uptake of graphene in several xenograft tumor mouse models. Moreover, to combine the two applications, authors showed a strong optical absorbance in the near-infrared region for in vivo PTT with a good ablation of cancer cells.

The majority of research groups joint the imaging properties with the drug delivery applications. Chen et al. used as well as $\mathrm{Hu} \mathrm{SH}$ et al. graphene conjugated with Qdots for targeted cancer fluorescent imaging, tracking and monitoring the delivery of drug into the cancer site $[59,96]$.

Cornelissen et al. [126] used GO coupled with anti-Her2 antibody, amonoclonal antibody for the treatment of breast cancer, and radiolabeled it with [In $\left.{ }^{111}\right]$-benzyl-diethylene-triaminepenta acetic acid via п-п-stacking for targeted and functional imaging. This construct [103] has shown an improvement in the targeting and therapy of breast cancer cells in mouse model compared to anti-Her2 alone. Indeed, the authors showed a clear in vivo visualization of the tumor using single-photon emission computed tomography.

\section{Combined therapy and theranostics}

All great potential of graphene in many cancer therapies (drug delivery, PTT and PDT) encouraged many authors to test graphene also combining different approaches for cancer treatment (see table 1) $[36,37,60-64,80-84,89,92,102,106]$.

Among this type of works, the higher number of studies (11 in total), herein analyzed, used graphene for combining drug delivery and PTT. Thanks to graphene properties, the authors combined both therapies in a single system enhancing the efficacy of the single modality. A clear example of these enhancements is well explained in the work of Feng et al. were the authors used GO as a carrier for siRNA and pDNA [89]. They showed that PTT induced local heating and accelerated intracellular trafficking of GO vectors, opening interesting new applications for combined therapies [89]. The same group, in another work, combined the DOX function with the PTT treatment. They showed a remarkably improved cell killing for drug-resistant cancer cells in comparison with free DOX. Other therapies, such as PTT and PDT, were combined only in three works herein reported. Previously, we described the works of Sahu et al. and Gollavelli et al. [103, 106]; their findings underlined the potential of GO for a synergistic combination of PDT with PTT. 
Drug delivery and PDT were combined in three works [37, 60, 80]. Zhou et al. [80] have combined GO with hypocrellin A and Camptothecin. Their results showed that the combination of drug delivery and PDT exhibited a synergistic antiproliferative effect compared with PDT and drug delivery alone. All works taken in consideration on combined therapies displayed very interesting possibilities to reach the ultimate purpose to fight cancer.

The great and innovative property of graphene is its good imaging characteristics that has prompted many Authors to combined imaging with one-therapy applications (i.e. drug delivery or phototermal therapy as shown in figure $2 B$ ) $[28,33,35,45,58,59,77-79$, $85,87,88,90,96,97,100,101,107,117,121]$. The largest number of studies herein cited and commented (12) combined the imaging properties of graphene with the good loading ability in drug delivery and gene delivery (see table 1). The first study that used this approach was Sun et al. they explored for the first time the ability of graphene as a theranostics tool indeed they found that the novel graphitic nanostructures, combined with multi-functionalities including biocompatibility, photoluminescence and drug loading and delivery, suggest promising applications of graphene materials in biological and medical areas [33]. This previous report open the way for all the further study that improve this findings improving the ability of graphene also as a combined materials. Thanks to graphene also PTT and PDT were combined with imaging, we found 8 works herein analyzed that used this strategy. Yang et al. was the first study that used graphene for PTT and imaging for give the successful ablation of breast cancer [28]. All these studies reached the purpose to fight cancer more effectively showing graphene as one of the most promising nanomaterial to reach the goal of cure cancer. On the other hand, three additional works [84, $102,106]$ used graphene for combined therapies and imaging. This type of approach is expected to grow fast in the next years, suggesting an exponentially growing success of graphene for more theranostic applications.

\section{Conclusion and perspectives}

In summary, all studies herein analyzed underline the potential of graphene in the theranostic field that allow concomitantly the diagnosis and the therapy of a tumor area.

Many works pointed out that different biomolecules such as siRNA, DNA and anticancer drugs such as doxorubicin can be loaded onto the surface of graphene for gene transfection and drug delivery. Moreover, the property of graphene to adsorb light in the NIR region has been tested from many research groups in phototherapy for in vivo and in vitro cancer treatment. This action combined with drug delivery and imaging could be used in a synergic treatment of cancer, increasing the targeted killing with less impairment of healthy cells. Furthermore, many studies, thanks to the graphene optical properties and the loading ability, tested this nanomaterial also in the phothodynamic treatment. We showed that graphene alone or conjuged with various inorganic nanoparticles such as Qdots, gold nanoparticles, magnetic iron nanoparticles and also loaded with fluorescent dye have all the potential to be used in many types of imaging such as optical imaging, ultrasonography, nuclear imaging and MRI. The great potential of graphene is the ability to provide at the same time many different cancer therapies joined to imaging make graphene one of the most promising next generation theranostic agents. Otherwise, further studies are still needed for the clinical translation of graphene in the context of cancer. In particular, it would be necessary to perform further investigations to prove the absence of toxicity and other side effects for healthy cells. For example, we previously noted the lack of studies focused on carbon materials interaction with immune cells [7, 130-132].

Furthermore, there are many discrepancies between the scientists in the context of toxicity of graphene. Several works reported a good biocompatibility and no cellular damage after exposure to graphene. However, other authors have evidenced cell toxicity with the enhancing of apoptosis and necrosis $[133,134]$. These variances in the scientific findings are especially due to the differences in size dimensions, functionalization and purification of the employed graphene samples.

Another point of interest is also related to graphene elimination from the living systems. Indeed how graphene is degraded and excreted is still not very well explained.

A better understanding of graphene and its derivatives behaviors in biological systems is needed to improve its performances also for theranostic applications. Although not only toxicology should be better addressed, but also the functionalization modalities and the conjugations of graphene that are important for its biocompatibility and pharmacokinetic profiles.

Here we give many interesting perspectives for new graphene-based studies about the treatment and diagnosis of various types of cancers, and especially breast cancer.

We believe that graphene is one of the most promising materials destined to change our day life and the future treatment and diagnosis of cancer. 


\section{Acknowledgments}

This work was partly supported by the Fondazione Banco di Sardegna (grant $\mathrm{N}^{\circ}$ 2013.1308, 2014.6035 to L.G.D.), the University of Sassari (Italy), the Sardinia Region (grant N ${ }^{\circ}$ CRP-59720 to L.G.D.), the Gianfranco del Prete Association "The future: medicine, biology and nanotechnology Award" to L.G.D. L.G.D. wishes to thank Sardinia Region for supporting an Invited Professorship to A.B. A.B. wishes to thank the Centre National de la Recherche Scientifique and the Agence Nationale de la Recherche (ANR) through the LabEx project Chemistry of Complex Systems (ANR-10-LABX-0026_CSC).

\section{Abbreviations}

CPT: Camptotecin; CT: computed tomography; DOX: Doxorubicin; GO: graphene oxide; MRI: magnetic resonance imaging; NIR: Near infrared region; OXA: oxaliplatin; PDT: Photodynamic therapy; PEG: Polyethylene glycol; PET: Positron emission tomography; PI: Photoacoustic imaging; PTT: Photothermal therapy; PVA: Poly(vinyl alcohol); QDots: Quantum dots; rGO: Reduced grapheme oxide; US: Ultrasonography.

\section{Competing Interests}

The authors have declared that no competing interest exists.

\section{References}

1. Lopez-Gomez M, Malmierca E, de Gorgolas M, Casado E. Cancer in developing countries: the next most preventable pandemic. The global problem of cancer. Critical reviews in oncology/hematology. 2013; 88: 117-22. doi:10.1016/j.critrevonc.2013.03.011

2. Jemal A, Bray F, Center MM, Ferlay J, Ward E, Forman D. Global cancer statistics. CA: a cancer journal for clinicians. 2011; 61: 69-90. doi:10.3322/caac.20107.

3. Madeddu R, Solinas G, Forte G, Bocca B, Asara Y, Tolu P, et al. Diet and nutrients are contributing factors that influence blood cadmium levels. Nutrition research. 2011; 31: 691-7. doi:10.1016/j.nutres.2011.09.003.

4. Fernandez-Fernandez A, Manchanda R, McGoron AJ. Theranostic applications of nanomaterials in cancer: drug delivery, image-guided therapy, and multifunctional platforms. Applied biochemistry and biotechnology. 2011; 165: 1628-51. doi:10.1007/s12010-011-9383-Z.

5. Shanmugam V, Selvakumar S, Yeh CS. Near-infrared light-responsive nanomaterials in cancer therapeutics. Chemical Society reviews. 2014; 43: 6254-87. doi:10.1039/c4cs00011k

6. Sechi G, Bedognetti D, Sgarrella F, Van Eperen L, Marincola FM, Bianco A, et al. The perception of nanotechnology and nanomedicine: a worldwide social media study. Nanomedicine. 2014; 9: 1475-86. doi:10.2217/nnm.14.78.

7. Orecchioni M, Bedognetti D, Sgarrella F, Marincola FM, Bianco A, Delogu LG Impact of carbon nanotubes and graphene on immune cells. Journal of translational medicine. 2014; 12: 138. doi:10.1186/1479-5876-12-138.

8. Servant A, Bianco A, Prato M, Kostarelos K. Graphene for multi-functional synthetic biology: the last 'zeitgeist' in nanomedicine. Bioorganic \& medicinal chemistry letters. 2014; 24: 1638-49. doi:10.1016/j.bmcl.2014.01.051

9. Shen $\mathrm{H}$, Zhang L, Liu M, Zhang Z. Biomedical applications of graphene. Theranostics. 2012; 2: 283-94. doi:10.7150/thno.3642.

10. Geim AK, Novoselov KS. The rise of graphene. Nature materials. 2007; 6: 183-91. doi:10.1038/nmat1849.

11. Geim AK. Graphene: status and prospects. Science. 2009; 324: 1530-4. doi:10.1126/science.1158877.

12. Palermo V. Not a molecule, not a polymer, not a substrate... the many faces of graphene as a chemical platform. Chemical communications. 2013; 49: 2848-57. doi: $10.1039 / \mathrm{c} 3 \mathrm{cc} 37474 \mathrm{~b}$.

13. Gao W, Alemany LB, Ci L, Ajayan PM. New insights into the structure and reduction of graphite oxide. Nature chemistry. 2009; 1: 403-8, doi:10.1038/nchem.281.

14. Bianco A, Cheng HM, Enoki T, Gogotsi $\mathrm{Y}$, Hurt RH, Koratkar N, et al. All in the graphene family - A recommended nomenclature for two-dimensional carbon materials. Carbon. 2013; 65: 1-6. doi:Doi 10.1016/J.Carbon.2013.08.038.
15. Zhang L, Xia J, Zhao Q, Liu L, Zhang Z. Functional graphene oxide as a nanocarrier for controlled loading and targeted delivery of mixed anticancer drugs. Small. 2010; 6: 537-44. doi:10.1002/smll.200901680.

16. Feng L, Zhang S, Liu Z. Graphene based gene transfection. Nanoscale. 2011; 3: 1252-7. doi:10.1039/c0nr00680g.

17. Dinescu S, Ionita M, Pandele AM, Galateanu B, Iovu $\mathrm{H}$, Ardelean A, et al. In vitro cytocompatibility evaluation of chitosan/graphene oxide 3D scaffold composites designed for bone tissue engineering. Bio-medical materials and engineering. 2014; 24: 2249-56. doi:10.3233/BME-141037.

18. Cveticanin J, Joksic G, Leskovac A, Petrovic S, Sobot AV, Neskovic O. Using carbon nanotubes to induce micronuclei and double strand breaks of the DNA in human cells. Nanotechnology. 2010; 21: 015102. doi:10.1088/0957-4484/21/1/015102.

19. Russier J, Treossi E, Scarsi A, Perrozzi F, Dumortier H, Ottaviano L, et al. Evidencing the mask effect of graphene oxide: a comparative study on primary human and murine phagocytic cells. Nanoscale. 2013; 5: 11234-47. doi:10.1039/c3nr03543c.

20. Jaworski S, Sawosz E, Grodzik M, Winnicka A, Prasek M, Wierzbicki M, et al. In vitro evaluation of the effects of graphene platelets on glioblastoma multiforme cells. International journal of nanomedicine. 2013; 8: 413-20. doi:10.2147/IJN.S39456.

21. Gurunathan S, Han J, Park JH, Kim JH. An in vitro evaluation of graphene oxide reduced by Ganoderma spp. in human breast cancer cells (MDA-MB-231). International journal of nanomedicine. 2014; 9: 1783-97. doi:10.2147/IJN.S57735.

22. Zhou H, Zhang B, Zheng J, Yu M, Zhou $\mathrm{T}$, Zhao K, et al. The inhibition of migration and invasion of cancer cells by graphene via the impairment of mitochondrial respiration. Biomaterials. 2014; 35: 1597-607. doi:10.1016/j.biomaterials.2013.11.020.

23. Yang K, Feng L, Shi X, Liu Z. Nano-graphene in biomedicine: theranostic applications. Chemical Society reviews. 2013; 42: 530-47. doi:10.1039/c2cs35342c.

24. Rastogi V, Yadav P, Bhattacharya SS, Mishra AK, Verma N, Verma A, et al. Carbon nanotubes: an emerging drug carrier for targeting cancer cells. Journal of drug delivery. 2014; 2014: 670815. doi:10.1155/2014/670815.

25. Delogu LG, Magrini A, Bergamaschi A, Rosato N, Dawson MI, Bottini N, et al. Conjugation of antisense oligonucleotides to PEGylated carbon nanotubes enables efficient knockdown of PTPN22 in T lymphocytes. Bioconjugate chemistry. 2009; 20: 427-31. doi:10.1021/bc800540j

26. Delogu LG, Stanford SM, Santelli E, Magrini A, Bergamaschi A, Motamedchaboki K, et al. Carbon nanotube-based nanocarriers: the importance of keeping it clean. Journal of nanoscience and nanotechnology. 2010; 10: 5293-301.

27. Feng $\mathrm{L}$, Liu $\mathrm{Z}$. Graphene in biomedicine: opportunities and challenges. Nanomedicine 2011: 6: 317-24 doi:10.2217/nnm 10.158

28. Yang K, Zhang S, Zhang G, Sun X, Lee ST, Liu Z. Graphene in mice: ultrahigh in vivo tumor uptake and efficient photothermal therapy. Nano letters. 2010; 10: 3318-23. doi:10.1021/nl100996u.

29. Delogu LG, Vidili G, Venturelli E, Menard-Moyon C, Zoroddu MA, Pilo G, et al. Functionalized multiwalled carbon nanotubes as ultrasound contrast agents. Proceedings of the National Academy of Sciences of the United States of America. 2012; 109: 16612-7. doi:10.1073/pnas.1208312109.

30. Zhang H, Yee D, Wang C. Quantum dots for cancer diagnosis and therapy: biological and clinical perspectives. Nanomedicine. 2008; 3: 83-91. doi:10.2217/17435889.3.1.83.

31. Ferlay J, Soerjomataram I, Dikshit R, Eser S, Mathers C, Rebelo M, et al. Cancer incidence and mortality worldwide: Sources, methods and major patterns in GLOBOCAN 2012. International journal of cancer Journal international du cancer. 2015; 136: E359-E86. doi:10.1002/ijc.29210.

32. Sahoo NG, Bao $\mathrm{H}$, Pan $\mathrm{Y}$, Pal M, Kakran M, Cheng HK, et al. Functionalized carbon nanomaterials as nanocarriers for loading and delivery of a poorly water-soluble anticancer drug: a comparative study. Chemical communications. 2011; 47: 5235-7. doi:10.1039/c1cc00075f.

33. Sun X, Liu Z, Welsher K, Robinson JT, Goodwin A, Zaric S, et al. Nano-Graphene Oxide for Cellular Imaging and Drug Delivery. Nano research. 2008; 1: 203-12. doi:10.1007/s12274-008-8021-8.

34. Kakran M, Sahoo NG, Bao H, Pan Y, Li L. Functionalized graphene oxide as nanocarrier for loading and delivery of ellagic Acid. Current medicinal chemistry. 2011; 18: 4503-12.

35. Kim H, Namgung R, Singha K, Oh IK, Kim WJ. Graphene oxide-polyethylenimine nanoconstruct as a gene delivery vector and bioimaging tool. Bioconjugate chemistry. 2011; 22: 2558-67. doi:10.1021/bc200397j.

36. Zhang W, Guo Z, Huang D, Liu Z, Guo X, Zhong H. Synergistic effect of chemo-photothermal therapy using PEGylated graphene oxide. Biomaterials. 2011; 32: 8555-61. doi:10.1016/j.biomaterials.2011.07.071.

37. Tian B, Wang C, Zhang S, Feng L, Liu Z. Photothermally enhanced photodynamic therapy delivered by nano-graphene oxide. ACS nano. 2011; 5: 7000-9. doi:10.1021/nn201560b.

38. Lu YJ, Yang HW, Hung SC, Huang CY, Li SM, Ma CC, et al. Improving thermal stability and efficacy of BCNU in treating glioma cells using PAA-functionalized graphene oxide. International journal of nanomedicine. 2012; 7: 1737-47. doi:10.2147/IJN.S29376.

39. Hu H, Yu J, Li Y, Zhao J, Dong H. Engineering of a novel pluronic F127/graphene nanohybrid for $\mathrm{pH}$ responsive drug delivery. Journal of biomedical materials research Part A. 2012; 100: 141-8. doi:10.1002/jbm.a.33252.

40. Wu J, Wang YS, Yang XY, Liu YY, Yang JR, Yang R, et al. Graphene oxide used as a carrier for adriamycin can reverse drug resistance in breast cancer cells. Nanotechnology. 2012; 23: 355101. doi:10.1088/0957-4484/23/35/355101.

41. Zheng XT, Li CM. Restoring basal planes of graphene oxides for highly efficient loading and delivery of beta-lapachone. Molecular pharmaceutics. 2012; 9: 615-21. doi:10.1021/mp2005356.

42. Yang $Y$, Zhang YM, Chen $Y$, Zhao D, Chen JT, Liu Y. Construction of a graphene oxide based noncovalent multiple nanosupramolecular assembly as a scaffold for drug delivery. Chemistry. 2012; 18: 4208-15. doi:10.1002/chem.201103445.

43. Misra SK, Kondaiah P, Bhattacharya S, Rao CN. Graphene as a nanocarrier for tamoxifen induces apoptosis in transformed cancer cell lines of different origins. Small. 2012: 8: 131-43. doi:10.1002/smll.201101640.

44. Wei G, Yan M, Dong R, Wang D, Zhou X, Chen J, et al. Covalent modification of reduced graphene oxide by means of diazonium chemistry and use as a drug-delivery system. Chemistry. 2012; 18: 14708-16. doi:10.1002/chem.201200843. 
45. Hong $\mathrm{H}$, Yang $\mathrm{K}$, Zhang $\mathrm{Y}$, Engle JW, Feng $\mathrm{L}$, Yang $\mathrm{Y}$, et al. In vivo targeting and imaging of tumor vasculature with radiolabeled, antibody-conjugated nanographene. ACS nano. 2012; 6: 2361-70. doi:10.1021/nn204625e.

46. Kavitha T, Abdi SI, Park SY. pH-sensitive nanocargo based on smart polymer functionalized graphene oxide for site-specific drug delivery. Physical chemistry chemical physics : PCCP. 2013; 15: 5176-85. doi:10.1039/c3cp00008g.

47. Liu G, Shen H, Mao J, Zhang L, Jiang Z, Sun T, et al. Transferrin modified graphene oxide for glioma-targeted drug delivery: in vitro and in vivo evaluations. ACS applied materials \& interfaces. 2013; 5: 6909-14. doi:10.1021/am402128s

48. Yang HW, Hua MY, Hwang TL, Lin KJ, Huang CY, Tsai RY, et al. Non-invasive synergistic treatment of brain tumors by targeted chemotherapeutic delivery and amplified focused ultrasound-hyperthermia using magnetic nanographene oxide. Advanced materials. 2013; 25: 3605-11. doi:10.1002/adma.201301046.

49. Jin R, Ji X, Yang Y, Wang H, Cao A. Self-assembled graphene-dextran nanohybrid for killing drug-resistant cancer cells. ACS applied materials \& interfaces. 2013; 5: 7181-9. doi:10.1021/am401523y

50. Wang C, Wu C, Zhou X, Han T, Xin X, Wu J, et al. Enhancing cell nucleus accumulation and DNA cleavage activity of anti-cancer drug via graphene quantum dots. Scientific reports. 2013; 3: 2852. doi:10.1038/srep02852.

51. Zhi F, Dong H, Jia X, Guo W, Lu H, Yang Y, et al. Functionalized graphene oxide mediated adriamycin delivery and miR-21 gene silencing to overcome tumor multidrug resistance in vitro. PloS one. 2013; 8: e60034. doi:10.1371/journal.pone.0060034

52. Kim H, Lee D, Kim J, Kim TI, Kim WJ. Photothermally triggered cytosolic drug delivery via endosome disruption using a functionalized reduced graphene oxide. ACS nano. 2013; 7: 6735-46. doi:10.1021/nn403096s

53. Liu CW, Xiong F, Jia HZ, Wang XL, Cheng $\mathrm{H}$, Sun $\mathrm{YH}$, et al. Graphene-based anticancer nanosystem and its biosafety evaluation using a zebrafish model. Biomacromolecules. 2013; 14: 358-66. doi:10.1021/bm3015297.

54. Miao W, Shim G, Kang CM, Lee S, Choe YS, Choi HG, et al. Cholesteryl hyaluronic acid-coated, reduced graphene oxide nanosheets for anti-cancer drug delivery. Biomaterials. 2013; 34: 9638-47. doi:10.1016/j.biomaterials.2013.08.058.

55. Fan X, Jiao G, Zhao W, Jin P, Li X. Magnetic Fe3O4-graphene composites as targeted drug nanocarriers for $\mathrm{pH}$-activated release. Nanoscale. 2013; 5: 1143-52. doi:10.1039/c2nr33158f.

56. Arya N, Arora A, Vasu KS, Sood AK, Katti DS. Combination of single walled carbon nanotubes/graphene oxide with paclitaxel: a reactive oxygen species mediated synergism for treatment of lung cancer. Nanoscale. 2013; 5: 2818-29. doi:10.1039/c3nr33190c.

57. Yin D, Li Y, Lin H, Guo B, Du Y, Li X, et al. Functional graphene oxide as a plasmid-based Stat3 siRNA carrier inhibits mouse malignant melanoma growth in vivo Nanotechnology. 2013: 24: 105102 doi:10.1088/0957-4484/24/10/105102.

58. Shi S, Yang K, Hong H, Valdovinos HF, Nayak TR, Zhang Y, et al. Tumor vasculature targeting and imaging in living mice with reduced graphene oxide. Biomaterials. 2013; 34: 3002-9. doi:10.1016/j.biomaterials.2013.01.047

59. Chen ML, He YJ, Chen XW, Wang JH. Quantum-dot-conjugated graphene as a probe for simultaneous cancer-targeted fluorescent imaging, tracking, and monitoring drug delivery. Bioconjugate chemistry. 2013; 24: 387-97. doi:10.1021/bc3004809.

60. Miao W, Shim G, Lee S, Lee S, Choe YS, Oh YK. Safety and tumor tissue accumulation of pegylated graphene oxide nanosheets for co-delivery of anticancer drug and photosensitizer. Biomaterials. 2013; 34: 3402-10. doi:10.1016/j.biomaterials.2013.01.010.

61. Wang Y, Wang K, Zhao J, Liu X, Bu J, Yan X, et al. Multifunctional mesoporous silica-coated graphene nanosheet used for chemo-photothermal synergistic targeted therapy of glioma. Journal of the American Chemical Society. 2013; 135: 4799-804. doi:10.1021/ja312221g.

62. Yang HW, Lu YJ, Lin KJ, Hsu SC, Huang CY, She SH, et al. EGRF conjugated PEGylated nanographene oxide for targeted chemotherapy and photothermal therapy. Biomaterials. 2013; 34: 7204-14. doi:10.1016/j.biomaterials.2013.06.007.

63. Qin XC, Guo ZY, Liu ZM, Zhang W, Wan MM, Yang BW. Folic acid-conjugated graphene oxide for cancer targeted chemo-photothermal therapy. Journal of photochemistry and photobiology B, Biology. 2013; 120: 156-62. doi:10.1016/j.jphotobiol.2012.12.005.

64. Wang C, Mallela J, Garapati US, Ravi S, Chinnasamy V, Girard Y, et al. A chitosan-modified graphene nanogel for noninvasive controlled drug release. Nanomedicine. 2013; 9: 903-11. doi:10.1016/j.nano.2013.01.003

65. Chaudhari NS, Pandey AP, Patil PO, Tekade AR, Bari SB, Deshmukh PK. Graphene oxide based magnetic nanocomposites for efficient treatment of breast cancer. Materials science \& engineering C, Materials for biological applications. 2014; 37: 278-85. doi:10.1016/j.msec.2014.01.007.

66. Zhang YM, Cao Y, Yang Y, Chen JT, Liu Y. A small-sized graphene oxide supramolecular assembly for targeted delivery of camptothecin. Chemical communications. 2014; 50: 13066-9. doi:10.1039/c4cc04533e.

67. Kavitha T, Kang IK, Park SY. Poly(N-vinyl caprolactam) grown on nanographene oxide as an effective nanocargo for drug delivery. Colloids and surfaces B, Biointerfaces. 2014; 115: 37-45. doi:10.1016/j.colsurfb.2013.11.022

68. Maity AR, Chakraborty A, Mondal A, Jana NR. Carbohydrate coated, folate functionalized colloidal graphene as a nanocarrier for both hydrophobic and hydrophilic drugs. Nanoscale. 2014; 6: 2752-8. doi:10.1039/c3nr05431d.

69. Chen H, Wang Z, Zong S, Wu L, Chen P, Zhu D, et al. SERS-fluorescence monitored drug release of a redox-responsive nanocarrier based on graphene oxide in tumor cells. ACS applied materials \& interfaces. 2014; 6: 17526-33. doi:10.1021/am505160v.

70. Chen GY, Chen CL, Tuan HY, Yuan PX, Li KC, Yang HJ, et al. Graphene oxide triggers toll-like receptors/autophagy responses in vitro and inhibits tumor growth in vivo. Advanced healthcare materials. 2014; 3: 1486-95. doi:10.1002/adhm.201300591.

71. Joseph D, Seo S, Williams DR, Geckeler KE. Double-stranded DNA-graphene hybrid: preparation and anti-proliferative activity. ACS applied materials \& interfaces. 2014; 6: 3347-56, doi:10.1021/am405378x.

72. Chowdhury SM, Surhland C, Sanchez Z, Chaudhary P, Suresh Kumar MA, Lee S, et al. Graphene nanoribbons as a drug delivery agent for lucanthone mediated therapy of glioblastoma multiforme. Nanomedicine. 2014. doi:10.1016/j.nano.2014.08.001
73. Yang $X$, Zhao N, Xu FJ. Biocleavable graphene oxide based-nanohybrids synthesized via ATRP for gene/drug delivery. Nanoscale. 2014; 6: 6141-50. doi:10.1039/c4nr00907j.

74. Song E, Han W, Li C, Cheng D, Li L, Liu L, et al. Hyaluronic acid-decorated graphene oxide nanohybrids as nanocarriers for targeted and $\mathrm{pH}$-responsive anticancer drug delivery. ACS applied materials \& interfaces. 2014; 6: 11882-90. doi:10.1021/am502423r

75. Zhao X, Liu L, Li X, Zeng J, Jia X, Liu P. Biocompatible graphene oxide nanoparticle-based drug delivery platform for tumor microenvironment-responsive triggered release of doxorubicin. Langmuir : the ACS journal of surfaces and colloids. 2014; 30: 10419-29 doi:10.1021/la502952f

76. Xu Z, Wang S, Li Y, Wang M, Shi P, Huang X. Covalent functionalization of graphene oxide with biocompatible poly(ethylene glycol) for delivery of paclitaxel. ACS applied materials \& interfaces. 2014; 6: 17268-76. doi:10.1021/am505308f.

77. He D, He X, Wang K, Zou Z, Yang X, Li X. Remote-controlled drug release from graphene oxide-capped mesoporous silica to cancer cells by photoinduced $\mathrm{pH}$-jump activation. Langmuir : the ACS journal of surfaces and colloids. 2014; 30: 7182-9. doi:10.1021/la501075c

78. Some S, Gwon AR, Hwang E, Bahn GH, Yoon Y, Kim Y, et al. Cancer therapy using ultrahigh hydrophobic drug-loaded graphene derivatives. Scientific reports. 2014; 4: 6314. doi: $10.1038 /$ srep06314.

79. Wang C, Chen B, Zou M, Cheng G. Cyclic RGD-modified chitosan/graphene oxide polymers for drug delivery and cellular imaging. Colloids and surfaces B, Biointerfaces. 2014; 122: 332-40. doi:10.1016/j.colsurfb.2014.07.018.

80. Zhou L, Zhou L, Wei S, Ge X, Zhou J, Jiang H, et al. Combination of chemotherapy and photodynamic therapy using graphene oxide as drug delivery system. Journal of photochemistry and photobiology B, Biology. 2014; 135: 7-16. doi:10.1016/j.jphotobiol.2014.04.010.

81. Shi J, Wang L, Zhang J, Ma R, Gao J, Liu Y, et al. A tumor-targeting near-infrared laser-triggered drug delivery system based on $\mathrm{GO} @ \mathrm{Ag}$ nanoparticles for chemo-photothermal therapy and X-ray imaging. Biomaterials. 2014; 35: 5847-61. doi:10.1016/j.biomaterials.2014.03.042

82. Bai J, Liu Y, Jiang X. Multifunctional PEG-GO/CuS nanocomposites for near-infrared chemo-photothermal therapy. Biomaterials. 2014; 35: 5805-13. doi:10.1016/j.biomaterials.2014.04.008.

83. Wan H, Zhang Y, Liu Z, Xu G, Huang G, Ji Y, et al. Facile fabrication of a near-infrared responsive nanocarrier for spatiotemporally controlled chemo-photothermal synergistic cancer therapy. Nanoscale. 2014; 6: 8743-53. doi:10.1039/c4nr01044b

84. Bian X, Song ZL, Qian Y, Gao W, Cheng ZQ, Chen L, et al. Fabrication of graphene-isolated-Au-nanocrystal nanostructures for multimodal cell imaging and photothermal-enhanced chemotherapy. Scientific reports. 2014; 4: 6093. doi:10.1038/srep06093.

85. Zhang M, Cao Y, Chong Y, Ma Y, Zhang H, Deng Z, et al. Graphene oxide based theranostic platform for T1-weighted magnetic resonance imaging and drug delivery. ACS applied materials \& interfaces. 2013; 5: 13325-32. doi:10.1021/am404292e.

86. Saeed LM, Mahmood M, Pyrek SJ, Fahmi T, Xu Y, Mustafa T, et al. Single-walled carbon nanotube and graphene nanodelivery of gambogic acid increases its cytotoxicity in breast and pancreatic cancer cells. Journal of applied toxicology : JAT. 2014; 34: 1188-99. doi:10.1002/jat.3018

87. Wang C, Ravi S, Garapati US, Das M, Howell M, MallelaMallela I, et al. Multifunctional Chitosan Magnetic-Graphene (CMG) Nanoparticles: a Theranostic Platform for Tumor-targeted Co-delivery of Drugs, Genes and MRI Contrast Agents. Journal of materials chemistry B, Materials for biology and medicine. 2013; 1 : 4396-405. doi:10.1039/C3TB20452A.

88. Gao Y, Zou X, Zhao JX, Li Y, Su X. Graphene oxide-based magnetic fluorescent hybrids for drug delivery and cellular imaging. Colloids and surfaces B, Biointerfaces. 2013; 112: 128-33. doi:10.1016/j.colsurfb.2013.07.020.

89. Feng L, Yang X, Shi X, Tan X, Peng R, Wang J, et al. Polyethylene glycol and polyethylenimine dual-functionalized nano-graphene oxide for photothermally enhanced gene delivery. Small. 2013; 9: 1989-97. doi:10.1002/smll.201202538.

90. Wang $Y$, Huang R, Liang G, Zhang Z, Zhang P, Yu S, et al. MRI-visualized, dual-targeting, combined tumor therapy using magnetic graphene-based mesoporous silica. Small. 2014; 10: 109-16. doi:10.1002/smll.201301297.

91. Chen GY, Meng CL, Lin KC, Tuan HY, Yang HJ, Chen CL, et al. Graphene oxide as a chemosensitizer: Diverted autophagic flux, enhanced nuclear import, elevated necrosis and improved antitumor effects. Biomaterials. 2015; 40: 12-22. doi:10.1016/j.biomaterials.2014.11.034

92. Feng L, Li K, Shi X, Gao M, Liu J, Liu Z. Smart pH-responsive nanocarriers based on nano-graphene oxide for combined chemo- and photothermal therapy overcoming drug resistance. Advanced healthcare materials. 2014; 3: 1261-71. doi:10.1002/adhm 201300549

93. Tomei S, Wang E, Delogu LG, Marincola FM, Bedognetti D. Non-BRAF-targeted therapy, immunotherapy, and combination therapy for melanoma. Expert opinion on biological therapy. 2014; 14: 663-86. doi:10.1517/14712598.2014.890586.

94. Bedognetti D, Spivey TL, Zhao Y, Uccellini L, Tomei S, Dudley ME, et al. CXCR3/CCR5 pathways in metastatic melanoma patients treated with adoptive therapy and interleukin-2. British journal of cancer. 2013; 109: 2412-23. doi:10.1038/bjc. 2013.557 .

95. Robinson JT, Tabakman SM, Liang Y, Wang H, Casalongue HS, Vinh D, et al. Ultrasmall reduced graphene oxide with high near-infrared absorbance for photothermal therapy. Journal of the American Chemical Society. 2011; 133: 6825-31. doi: $10.1021 /$ ja2010175.

96. Hu SH, Chen YW, Hung WT, Chen IW, Chen SY. Quantum-dot-tagged reduced graphene oxide nanocomposites for bright fluorescence bioimaging and photothermal therapy monitored in situ. Advanced materials. 2012; 24: 1748-54. doi:10.1002/adma.201104070.

97. Yang K, Hu L, Ma X, Ye S, Cheng L, Shi X, et al. Multimodal imaging guided photothermal therapy using functionalized graphene nanosheets anchored with magnetic nanoparticles. Advanced materials. 2012; 24: 1868-72. doi:10.1002/adma.201104964 
98. Yang $\mathrm{K}$, Wan J, Zhang S, Tian B, Zhang $\mathrm{Y}$, Liu Z. The influence of surface chemistry and size of nanoscale graphene oxide on photothermal therapy of cancer using ultra-low laser power. Biomaterials. 2012; 33: 2206-14. doi:10.1016/j.biomaterials.2011.11.064.

99. Abdolahad M, Janmaleki M, Mohajerzadeh S, Akhavan O, Abbasi S. Polyphenols attached graphene nanosheets for high efficiency NIR mediated photodestruction of cancer cells. Materials science \& engineering C, Materials for biological applications. 2013; 33: 1498-505. doi:10.1016/j.msec.2012.12.052.

100. Sheng Z, Song L, Zheng J, Hu D, He M, Zheng M, et al. Protein-assisted fabrication of nano-reduced graphene oxide for combined in vivo photoacoustic imaging and photothermal therapy. Biomaterials. 2013; 34: 5236-43. doi:10.1016/j.biomaterials.2013.03.090

101. Jin Y, Wang J, Ke H, Wang S, Dai Z. Graphene oxide modified PLA microcapsules containing gold nanoparticles for ultrasonic/CT bimodal imaging guided photothermal tumor therapy. Biomaterials. 2013; 34: 4794-802. doi:10.1016/j.biomaterials.2013.03.027.

102. Wang Y, Wang H, Liu D, Song S, Wang X, Zhang H. Graphene oxide covalently grafted upconversion nanoparticles for combined NIR mediated imaging and photothermal/photodynamic cancer therapy. Biomaterials. 2013; 34: 7715-24. doi:10.1016/j.biomaterials.2013.06.045.

103. Sahu A, Choi WI, Lee JH, Tae G. Graphene oxide mediated delivery of methylene blue for combined photodynamic and photothermal therapy. Biomaterials. 2013; 34: 6239-48. doi:10.1016/j.biomaterials.2013.04.066.

104. Hou C, Quan H, Duan Y, Zhang Q, Wang H, Li Y. Facile synthesis of water-dispersible $\mathrm{Cu} 2 \mathrm{O}$ nanocrystal-reduced graphene oxide hybrid as a promising cancer therapeutic agent. Nanoscale. 2013; 5: 1227-32. doi:10.1039/c2nr32938g.

105. Shi X, Gong H, Li Y, Wang C, Cheng L, Liu Z. Graphene-based magnetic plasmonic nanocomposite for dual bioimaging and photothermal therapy. Biomaterials. 2013; 34: 4786-93. doi:10.1016/j.biomaterials.2013.03.023

106. Gollavelli G, Ling YC. Magnetic and fluorescent graphene for dual modal imaging and single light induced photothermal and photodynamic therapy of cancer cells. Biomaterials. 2014; 35: 4499-507. doi:10.1016/j.biomaterials.2014.02.011.

107. Nergiz SZ, Gandra N, Tadepalli S, Singamaneni S. Multifunctional hybrid nanopatches of graphene oxide and gold nanostars for ultraefficient photothermal cancer therapy. ACS applied materials \& interfaces. 2014; 6: 16395-402. doi:10.1021/am504795d.

108. Dembereldorj U, Choi SY, Ganbold EO, Song NW, Kim D, Choo J, et al. Gold nanorod-assembled PEGylated graphene-oxide nanocomposites for photothermal cancer therapy. Photochemistry and photobiology. 2014; 90: 659-66. doi:10.1111/php.12212.

109. Li JL, Hou XL, Bao HC, Sun L, Tang B, Wang JF, et al. Graphene oxide nanoparticles for enhanced photothermal cancer cell therapy under the irradiation of a femtosecond laser beam. Journal of biomedical materials research Part A. 2014; 102: 2181-8. doi:10.1002/jbm.a.34871.

110. Rong P, Yang K, Srivastan A, Kiesewetter DO, Yue X, Wang F, et al. Photosensitizer loaded nano-graphene for multimodality imaging guided tumor photodynamic therapy. Theranostics. 2014; 4: 229-39. doi:10.7150/thno.8070.

111. Wate PS, Banerjee SS, Jalota-Badhwar A, Mascarenhas RR, Zope KR, Khandare J, et al. Cellular imaging using biocompatible dendrimer-functionalized graphene oxide-based fluorescent probe anchored with magnetic nanoparticles. Nanotechnology. 2012; 23: 415101. doi:10.1088/0957-4484/23/41/415101.

112. Splinter R, and Brett A. Hooper. An introduction to biomedical optics. CRC Press; 2006.

113. Hirsch LR, Stafford RJ, Bankson JA, Sershen SR, Rivera B, Price RE, et al. Nanoshell-mediated near-infrared thermal therapy of tumors under magnetic resonance guidance. Proceedings of the National Academy of Sciences of the United States of America. 2003; 100: 13549-54. doi:10.1073/pnas.2232479100.

114. von Maltzahn G, Park JH, Agrawal A, Bandaru NK, Das SK, Sailor MJ, et al. Computationally guided photothermal tumor therapy using long-circulating gold nanorod antennas. Cancer research. 2009; 69: 3892-900. doi:10.1158/0008-5472.CAN-08-4242

115. Hasan $\mathrm{W}$, Stender $\mathrm{CL}$, Lee $\mathrm{MH}$, Nehl $\mathrm{CL}$, Lee J. Tailoring the structure of nanopyramids for optimal heat generation. Nano letters. 2009; 9: 1555-8. doi: $10.1021 / \mathrm{nl} 803647 \mathrm{n}$

116. Ghosh S, Dutta S, Gomes E, Carroll D, D'Agostino R, Jr., Olson J, et al. Increased heating efficiency and selective thermal ablation of malignant tissue with DNA-encased multiwalled carbon nanotubes. ACS nano. 2009; 3: 2667-73. doi: $10.1021 / \mathrm{nn} 900368 \mathrm{~b}$

117. Wang S, Zhang Q, Luo XF, Li J, He H, Yang F, et al. Magnetic graphene-based nanotheranostic agent for dual-modality mapping guided photothermal therapy in regional lymph nodal metastasis of pancreatic cancer. Biomaterials. 2014; 35: 9473-83. doi:10.1016/j.biomaterials.2014.07.064

118. Zhou $\mathrm{T}$, Zhang B, Wei $\mathrm{P}, \mathrm{Du} \mathrm{Y}$, Zhou $\mathrm{H}, \mathrm{Yu} \mathrm{M}$, et al. Energy metabolism analysis reveals the mechanism of inhibition of breast cancer cell metastasis by PEG-modified graphene oxide nanosheets. Biomaterials. 2014; 35: 9833-43. doi:10.1016/j.biomaterials.2014.08.033

119. Huang $\mathrm{P}, \mathrm{Xu} \mathrm{C}$, Lin J, Wang C, Wang X, Zhang C, et al. Folic Acid-conjugated Graphene Oxide loaded with Photosensitizers for Targeting Photodynamic Therapy. Theranostics. 2011; 1: 240-50.

120. Josefsen LB, Boyle RW. Unique diagnostic and therapeutic roles of porphyrins and phthalocyanines in photodynamic therapy, imaging and theranostics. Theranostics. 2012; 2: 916-66. doi:10.7150/thno.4571.

121. Ge J, Lan M, Zhou B, Liu W, Guo L, Wang H, et al. A graphene quantum dot photodynamic therapy agent with high singlet oxygen generation. Nature communications. 2014; 5: 4596. doi:10.1038/ncomms5596.

122. Hu Z, Huang YD, Sun SF, Guan WC, Yao YH, Tang PY, et al. Visible light driven photodynamic anticancer activity of graphene oxide/TiO2 hybrid. Carbon. 2012; 50: 994-1004. doi:Doi 10.1016/J.Carbon.2011.10.002.

123. Khdair A, Gerard B, Handa H, Mao G, Shekhar MP, Panyam J. Surfactant-polymer nanoparticles enhance the effectiveness of anticancer photodynamic therapy. Molecular pharmaceutics. 2008; 5: 795-807. doi:10.1021/mp800026t.
124. Austin M. Derfus WCWCaSNB. Probing the Cytotoxicity of Semiconductor Quantum Dots. Nano letters. 2004; 4

125. Li JL, Tang B, Yuan B, Sun L, Wang XG. A review of optical imaging and therapy using nanosized graphene and graphene oxide. Biomaterials. 2013; 34: 9519-34. doi:10.1016/j.biomaterials.2013.08.066

126. Cornelissen B, Able S, Kersemans V, Waghorn PA, Myhra S, Jurkshat K, et al. Nanographene oxide-based radioimmunoconstructs for in vivo targeting and SPECT imaging of HER2-positive tumors. Biomaterials. 2013; 34: 1146-54. doi:10.1016/j.biomaterials.2012.10.054

127. Yang HW, Huang CY, Lin CW, Liu HL, Huang CW, Liao SS, et al. Gadolinium-functionalized nanographene oxide for combined drug and microRNA delivery and magnetic resonance imaging. Biomaterials. 2014; 35: 6534-42. doi:10.1016/j.biomaterials.2014.04.057

128. Zhang LN, Deng HH, Lin FL, Xu XW, Weng SH, Liu AL, et al. In situ growth of porous platinum nanoparticles on graphene oxide for colorimetric detection of cancer cells. Analytical chemistry. 2014; 86: 2711-8. doi:10.1021/ac404104j.

129. Bianying F, Linjie G, Lihua W, Fan L, Jianxin L, Jimin G, et al. A graphene oxide-based fluorescent biosensor for the analysis of peptide-receptor interactions and imaging in somatostatin receptor subtype 2 overexpressed tumor cells. Analytical chemistry. 2013; 85: 7732-7. doi:10.1021/ac4009463.

130. Delogu LG, Venturelli E, Manetti R, Pinna GA, Carru C, Madeddu R, et al. Ex vivo impact of functionalized carbon nanotubes on human immune cells. Nanomedicine. 2012; 7: 231-43. doi:10.2217/nnm.11.101.

131. Pescatori M, Bedognetti D, Venturelli E, Menard-Moyon C, Bernardini C, Muresu E, et al. Functionalized carbon nanotubes as immunomodulator systems. Biomaterials. 2013; 34: 4395-403. doi:10.1016/j.biomaterials.2013.02.052

132. Crescio C, Orecchioni M, Menard-Moyon C, Sgarrella F, Pippia P, Manetti R, et al. Immunomodulatory properties of carbon nanotubes are able to compensate immune function dysregulation caused by microgravity conditions. Nanoscale. 2014; 6: 9599-603. doi:10.1039/c4nr02711f.

133. Sasidharan A, Panchakarla LS, Chandran P, Menon D, Nair S, Rao CN, et al. Differential nano-bio interactions and toxicity effects of pristine versus functionalized graphene. Nanoscale. 2011; 3: 2461-4. doi:10.1039/c1nr10172b.

134. Vallabani NV, Mittal S, Shukla RK, Pandey AK, Dhakate SR, Pasricha R, et al. Toxicity of graphene in normal human lung cells (BEAS-2B). Journal of biomedical nanotechnology. 2011; 7: 106-7. 